\title{
Substantial Climate Response outside the Target Area in an Idealized Experiment of Regional Radiation Management
}

\author{
Sudhakar Dipu ${ }^{1, *(\mathbb{D})}$, Johannes Quaas ${ }^{1}\left(\mathbb{D}\right.$, Martin Quaas $^{1,2}$, Wilfried Rickels ${ }^{3}$ and Johannes Mülmenstädt ${ }^{1,4}$ \\ and Olivier Boucher ${ }^{5,6}$ \\ 1 Institute for Meteorology, Universität Leipzig, 04109 Leipzig, Germany; johannes.quaas@uni-leipzig.de (J.Q.); \\ martin.quaas@idiv.de (M.Q.); johannes.muelmenstaedt@pnnl.gov (J.M.) \\ 2 German Centre for Integrative Biodiversity Research (iDiv), Halle-Jena-Leipzig, 04103 Leipzig, Germany \\ 3 Kiel Institute for the World Economy Kiel, 24105 Kiel, Germany; wilfried.rickels@ifw-kiel.de \\ 4 Presently at Pacific Northwest National Laboratory, Richland, WA 99354, USA \\ 5 Institut Pierre-Simon Laplace, Sorbonne Université, 75005 Paris, France; olivier.boucher@ipsl.fr \\ 6 CNRS, 75016 Paris, France \\ * Correspondence: dipu.sudhakar@uni-leipzig.de
}

check for

updates

Citation: Dipu, S.; Quaas, J.; Quaas, M.; Rickels, W.; Mülmenstädt, J.; Boucher, O. Substantial Climate Response outside the Target Area in an Idealized Experiment of Regional Radiation Management. Climate 2021, 9, 66. https://doi.org/10.3390/ cli9040066

Academic Editor: Rajib Shaw

Received: 15 March 2021

Accepted: 13 April 2021

Published: 16 April 2021

Publisher's Note: MDPI stays neutral with regard to jurisdictional claims in published maps and institutional affiliations.

Copyright: (c) 2021 by the authors. Licensee MDPI, Basel, Switzerland. This article is an open access article distributed under the terms and conditions of the Creative Commons Attribution (CC BY) license (https:/ / creativecommons.org/licenses/by/ $4.0 /)$.

\begin{abstract}
Radiation management (RM) has been proposed as a conceivable climate engineering (CE) intervention to mitigate global warming. In this study, we used a coupled climate model (MPI-ESM) with a very idealized setup to investigate the efficacy and risks of CE at a local scale in space and time (regional radiation management, RRM) assuming that cloud modification is technically possible. $\mathrm{RM}$ is implemented in the climate model by the brightening of low-level clouds (solar radiation management, SRM) and thinning of cirrus (terrestrial radiation management, TRM). The region chosen is North America, and we simulated a period of 30 years. The implemented sustained $\mathrm{RM}$ resulted in a net local radiative forcing of $-9.8 \mathrm{Wm}^{-2}$ and a local cooling of $-0.8 \mathrm{~K}$. Surface temperature (SAT) extremes (90th and 10th percentiles) show negative anomalies in the target region. However, substantial climate impacts were also simulated outside the target area, with warming in the Arctic and pronounced precipitation change in the eastern Pacific. As a variant of RRM, a targeted intervention to suppress heat waves (HW) was investigated in further simulations by implementing intermittent cloud modification locally, prior to the simulated HW situations. In most cases, the intermittent RRM results in a successful reduction of temperatures locally, with substantially smaller impacts outside the target area compared to the sustained RRM.
\end{abstract}

Keywords: regional radiation management; climate engineering; radiative forcing

\section{Introduction}

Climate engineering (CE), also referred to as geoengineering, encompasses a set of technologies and methods to deliberately intervene in the climate system to counteract global warming [1]. The approach consists of either reducing the amount of solar radiation absorbed by the Earth, facilitating outgoing long-wave radiation (radiation management, $\mathrm{RM}$ ) or enhancing the net carbon sink from the atmosphere (carbon dioxide removal, CDR) in order to mitigate global warming [2]. In the past few years, CE has garnered significant attention because, if adequate measures to curb greenhouse gases in the atmosphere are not implemented rapidly, substantial warming over pre-industrial times can be expected [3-6].

To tackle global warming, the Paris agreement (2015) aims to limit the increase in globalmean near-surface temperature to below $2{ }^{\circ} \mathrm{C}$ in comparison to pre-industrial times and to pursue efforts to limit the increase to below $1.5^{\circ} \mathrm{C}[7,8]$. Substantial reductions in greenhouse gas emissions as well as some amount of CDR are required to do so, but, if such measures are insufficient or come too late, achieving these goals would imply some sort of RM. However, $\mathrm{RM}$ is expected to be imperfect (e.g., it may lead to overcooling of the tropics and undercooling of the poles) with potentially severe side effects (e.g., it modifies some precipitation patterns). 
Furthermore, it would not solve the issues of ocean acidification and ocean deoxygenation, and a putative early termination would cause rapid climate change $[9,10]$. Thus, RM entails many social and ethical issues [11] which to some extent also apply to research on RM [12]. However, without a strong reduction in greenhouse gases and in the absence of CE methods (CDR and RM), anthropogenic climate change could result devastating consequences with $3-4{ }^{\circ} \mathrm{C}$ or more temperature rise by the end of the 21st century [13-16], which would also generate significant social and ethical concerns [17].

In this context, RM might be proposed to "shave off" the peak of climate warming due to anthropogenic greenhouse gases, before the $\mathrm{CO}_{2}$ removal and greenhouse gases mitigations become sufficient [3,10,18-20]. Quaas et al. (2016) [21] argued that local implementation of RM seems more likely than a global implementation. One key reason for this is that different countries or different regions of the world have different preferences with regard to climate change. A regional implementation might also occur as an interim step before global action is taken [22]. Various climate projections with RM techniques propose that the radiative forcing $(\mathrm{RF})$, a measure of energy budget perturbation, is substantially localized to the region of implementation [23-26].

Local mitigation seems a necessary but not a sufficient condition for regional RM (RRM) to be of interest, because the climate effects may extend outside the region. The extended climate effect may be beneficial or detrimental, while the pattern of influence strongly depends on the region of RRM implementation $[10,25]$. By using an example, here we demonstrate that RRM may lead to non-local responses which are modulated by the atmospheric circulation, and subsequently we demonstrate that limiting RRM also in time substantially reduces these side-effects.

Proposed RM management schemes involve reflecting solar radiation away from the Earth's atmosphere (solar radiation management, SRM [27]) and increasing the outgoing long-wave radiation at the top of the atmosphere (terrestrial radiation management, TRM $[26,28])$. SRM techniques aim to manipulate the global temperature by increasing the albedo of the atmosphere. Among CE options, some SRM techniques are potentially comparatively inexpensive, technologically feasible and would lead to a rapid response of the climate system $[29,30]$. SRM includes methods such as the sulfate aerosol injection into the stratosphere or increasing the reflectivity of low-level clouds, and possibly also their lifetime, by adding aerosols to the troposphere $[13,18,29,31-34]$.

The response of climate to stratospheric aerosol injection (SAI) has been investigated in many modeling studies (e.g., [10,18,19,24,25,34-37]). These suggest that SAI could possibly stabilize the global mean surface temperature. The problem that equatorial injection of stratospheric aerosols leads to an overcooling of the tropics relative to the higher latitudes can possibly be overcome by optimized injection at multiple locations [35]. SAI focusing on the polar regions can even have a larger influence in high compared to low latitudes [38,39]. Besides cooling, large-scale SAI could lead to consequences such as a shift in precipitation patterns [20,40], reduction in monsoon precipitation [41] and unmitigated characteristics of temperature and precipitation extremes [24]. Further, SAI would also delay the recovery of the ozone layer and enhance environmental risks [18,33,34,42]. However, MacMartin et al. (2019) [3] suggested that, for a limited deployment of SAI, the projected changes in surface temperature, precipitation and precipitation minus evaporation are typically smaller than natural variability.

In addition to SAI, marine cloud brightening (MCB) has been proposed as a possible SRM approach [43-45]. The suggestion is to modify low-level marine clouds by injecting aerosols into the marine boundary layer and so increase cloud albedo. Such modification would produce a negative RF, which implies a cooling of surface temperature [46]. This approach is most effective in relatively clean areas [43]. Ship tracks and the impact of volcanic eruptions on marine clouds provide observational evidence of the cloud albedo effect [47]. Several modeling studies reported that, in principle, MCB has the potential to cool the Earth substantially $[25,29,48]$. 
Aswathy et al. (2015) [24] examined multi-model simulations of SAI and MCB. They demonstrated that both methods offset the effect of global warming, with more cooling in lower latitudes and residual warming in the Arctic. Aswathy et al. (2015) [24] further discussed the discrepancy in extreme temperature and precipitation for the two different CE schemes (SAI and MCB). Finally, some studies suggest that sudden termination of SRM may cause an acceleration of global warming, which is another important risk of SRM [49,50]. However, the sudden termination of strong SRM implementation might not be the most realistic scenario [51].

Another way of manipulating the net radiative flux of the planet could be through the thinning of high-level cirrus clouds (deliberate reduction of the cloud cover and optical thickness) $[52,53]$. Cirrus thinning reduces the absorption of long-wave radiation emitted from the Earth's surface and the atmosphere beneath it, which results in a cooling $[26,54,55]$. However, altitude, optical depth, cloud microphysics and reflectivity of sunlight play a pivotal role in cirrus radiative effects [56,57]. Storelvmo et al. (2013) [58] tested the cirrus thinning hypothesis in a global climate model and found that it has the potential to counteract anthropogenic global warming. For cirrus cloud modification, a preliminary estimate of the potential global change in cloud radiative effect of up to $-2.8 \mathrm{Wm}^{-2}$ has been reported, which could almost offset the RF due to $\mathrm{CO}_{2}$ doubling [26]. However, the effect of this magnitude is quite theoretical. It could be a complementary measure to SAI if implemented regionally over polar regions in the winter season. However, cirrus thinning in the polar regions would modify the equator to the pole temperature gradient $[22,38,59]$.

Previous studies (some of which are discussed above) have provided insight into various RM methods, their efficacy and risks. Studies that have examined the possibility of RRM through the dimming of solar radiation were limited to the Arctic [39,59]. Outside the Arctic, RRM raises critical questions if different countries and regions of the world have a different perspective on climate change and/or CE. Nevertheless, it is essential to identify the regional response to climate change [60].

In this context, Quaas et al. (2016) [21] pointed out that RRM could further be limited by implementing them only "on demand" to target certain climate extreme events, in particular, heat waves (HW). It is much more homogenous than other climate extremes, for example, thunderstorms and extreme precipitations. From observations and model projections, it is evident that, with climate change, the present-day HWs are likely to become more frequent, intense and longer with a substantial impact on human health [61-65]. In recent decades, climate models are increasingly able to reproduce climate extremes as well as their response to forcings [66]. Wang et al. (2013) [67] simulated the effect of RRM by increasing the surface albedo of urban roofs, which allows for some HW suppression. This implies that mitigation measures such as RRM could potentially reduce the impact of the HW and its consequences.

In RM research, deployment scenarios play a pivotal role in assessing efficacy and risks. Most of the RM scenarios are aiming to offset the global mean temperature rise. However, the recent emphasis is on moderate and restrained deployment [68-70]. In this study, we considered the scenario of a regional intervention (local mitigation or RRM) in a mid-latitude region, using a state-of-the-art climate model under the assumption that cloud modification is technically possible. This study investigated the efficacy and impacts of regional mitigation by sustained RM, the HW suppression by intermittent RM and its impacts outside the target region.

\section{Data and Methodology}

\subsection{Model Description}

The simulations on which this study relies was performed with a coupled atmosphereocean-land surface model, the Max Planck Institute Earth system model (MPI-ESM) [71]. It consists of the atmospheric component ECHAM6 [72] with T63L47 spectral resolution (about $1.8^{\circ}$ in the horizontal, uppermost of the 47 levels at $0.01 \mathrm{hPa}$ ) and the ocean component Max Planck Institute Ocean Model (MPIOM) [73], which applies an idealized control mapping grid of about $1.5^{\circ}$ with 40 levels. The atmospheric composition, as well as other 
boundary conditions, are prescribed at pre-industrial conditions. The simulations were initialized with existing pre-industrial equilibrium simulation and were run for 30 years. The two reasons to choose the pre-industrial climate are: (i) the practical one that a balanced equilibrium atmosphere-ocean state is available; and (ii) that the analysis is facilitated since the only transient perturbation is the imposed one. Although we agree that RRM would be more realistically tested in a future scenario, it is very unlikely to change the results. The key mechanisms documented in our study would be equally present no matter what the baseline climate is. Furthermore, the choice of the scenario would be arbitrary.

\subsection{Experimental Design}

The aim of these experiments was an analysis of RRM, targeting a continental area encompassing $32.5^{\circ} \mathrm{N}$ to $47.5^{\circ} \mathrm{N}$ and $112.0^{\circ} \mathrm{W}$ to $92.0^{\circ} \mathrm{W}$ (Figure A1). North America was chosen somewhat arbitrarily, but there is one key argument: it is a mid-latitude region where no directly neighboring countries are located in the zonal direction, so that comparatively little effects of RRM in other countries may be expected. The exact location of the box within North America is arbitrary and again idealized.

Three types of model experiments were performed. First, a control simulation was performed without any cloud modification. A second type of simulations was performed where an idealized regional cloud modification (see Section 2.2.1) was sustained throughout the simulation over the targeted region. This second type of simulations is referred to as the "sustained mitigation" experiment and is evaluated against the control simulation. A third type of simulations was also performed where cloud modification was implemented only for the periods when in the control simulation there is a HW in the region of interest. This third type of simulations is used to evaluate the impact of "intermittent mitigation".

In the above case, the simulation is stopped a little after a HW is detected over the target area; it is then rewound and restarted with the cloud modification applied for a short period before, during and after the HW is simulated in the initial simulation. The scenario is meant to represent the fact that RRM is triggered and then a HW is forecast by numerical weather prediction. We define HW conditions as periods when the area mean of daily maximum temperature within the target region exceeds a threshold value, selected here as $32{ }^{\circ} \mathrm{C}$, for at least three consecutive days. In such an event, RRM is implemented starting 10 days preceding the HW (Figure A2). This 10-day period is a lead time at which numerical weather prediction is reliable, and long enough to allow the surface temperature to respond to the cloud modification. RRM is then sustained until one week after the end of the HW in the original simulation. The simulation with HW suppression then becomes the main simulation and is continued (consistent with the scenario, Figure A2). If multiple HW episode occurs within a period (less than 10 days between the HWs), then such events are combined and treated as a long single HW condition. In this third type of simulations, the periods with HW suppressions are evaluated against the corresponding periods without HW suppression that were simulated before the simulation is rewound to apply the cloud modification.

To reduce the uncertainty associated with the simulated interannual variability, a six-member ensemble was performed and analyzed. A small ensemble size would be sufficient for global mean temperature response, while, for deep ocean processes or some atmospheric extremes, a larger ensemble is required [74]. The ensemble members were performed only for sustained and intermittent experiments. For the sustained experiment, each ensemble member used the same external forcing besides a small perturbation in the atmospheric initial conditions. Thus, the statistics were performed on a period of $6 \times 30$ years $=180$ years. For the intermittent experiment, the perturbation was applied only during the HW suppression period (Figure A2).

The cloud modification influences the Earth's climate by perturbing the Earth's energy budget at the top of the atmosphere, which is referred to as the effective radiative forcing (ERF). It is defined as the difference between the net radiative flux at the top of the atmosphere for the experiment (with RRM) and the control simulation (without RRM). 
However, since the integration time is short enough, there is still the bulk of the top-ofatmosphere radiation imbalance that makes up the ERF. To compute statistical significance levels, a Welch's unpaired $t$-test was used $[75,76]$. In both experiments, a set of climate extremes was identified with the upper and lower end of the distribution of meteorological variables, for instance, top and bottom deciles (90th and 10th percentiles, respectively) of surface temperature [24]. In the following text, the changes in temperature, precipitation, wind, etc., are the mean changes over 30 years (experiment - control) and local/locally denote the experiment region.

\subsubsection{Cloud Modification}

Cloud optical properties have a profound impact on the global radiative effect [46]. Optically thick boundary layer clouds exert a negative radiative effect, by reflecting solar radiation and little greenhouse effect $[46,77]$, whereas optically thin high-level clouds have a positive radiative effect by blocking the terrestrial radiation [26]. Here, the cloud modification is implemented as an alteration to both types of clouds by multiplying the liquid cloud water content $q_{1}$ by a factor of 10 and multiplying the cloud ice content $q_{\mathrm{i}}$ by a factor of 0.1 in the model, specifically over the target region $\left(q_{1}\right.$ and $q_{\mathrm{i}}$ are local variables in the radiation module). This modification is made at every time step because the change does not affect processes other than the radiation. The change intentionally is large to obtain a climate signal. The MPI-ESM uses a single moment cloud microphysics scheme. A change in the cloud microphysics would modify the particle size, which feedbacks in the next time step to the changed cloud water content. This effectively assumes that, technologically, such a cloud modification is feasible and neglects possible implications of the specific technology. Since the above modification will work only if $q_{1}>0$ and/or $q_{\mathrm{i}}>0$, the magnitude of the cloud modification strongly depends on the presence and thermodynamic phase of cloud layers in the atmospheric column. The cloud modification effects scale about linearly with the forcing to a first approximation. Here, the climate model scales the liquid/ice to reduce the vapor, which conserves the cloud water.

\section{Results}

\subsection{Sustained Mitigation}

The implemented RM in the climate model (see Section 2.2.1) increases the reflection of solar radiation by liquid-water clouds (negative radiative effect) and reduces the cirrus greenhouse effect by allowing more terrestrial radiation to escape to space (i.e., to reduce the absorption of long-wave radiation emitted from the Earth's surface and the atmosphere beneath; negative radiative effect). Both lead to a negative local RF. Figure $1 \mathrm{a}$ shows the diagnosed effective RF (ERF) at the top of the atmosphere, which yields a magnitude of $-9.8 \pm 5 \mathrm{Wm}^{-2}$ over the target/experiment region. The negative forcing leads to a cooling of the near surface air temperature (SAT) with a mean of $-0.8 \pm 0.7 \mathrm{~K}$ in the target region (Figure 1b). Further, the mean temperature profile also illustrates a reduction compared to the control simulation (figure not shown). 

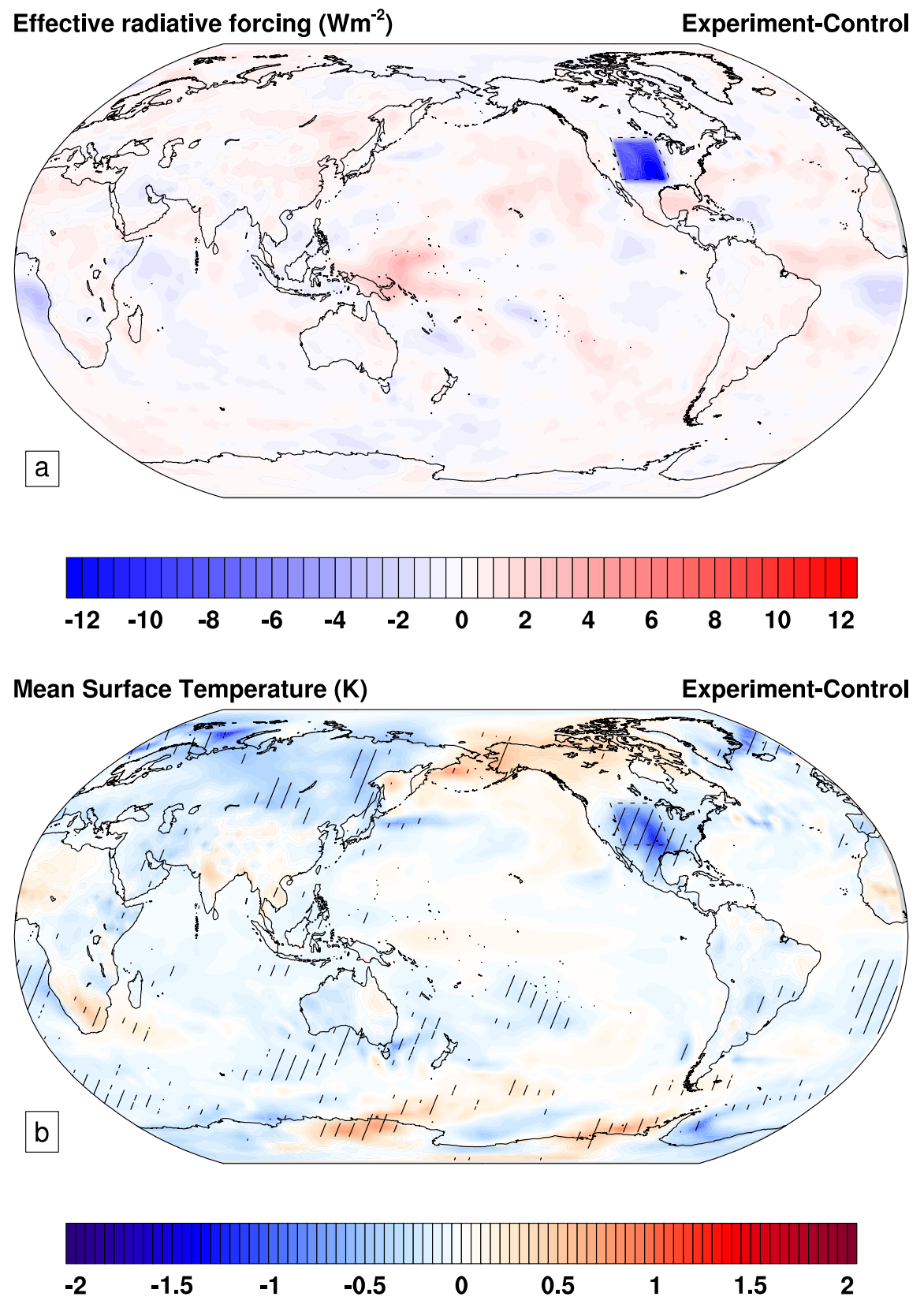

Figure 1. (a) Effective radiative forcing $\left(\mathrm{ERF}, \mathrm{Wm}^{-2}\right.$ ) at the top of the atmosphere; and (b) nearsurface air temperature (SAT, K) change as 30-year average (experiment - control), ensemble average differences between the sustained RRM and control simulations. Hatched areas are grid cells where the changes are statistically significant at the $90 \%$ level according to a $t$-test.

The radiative effect of RRM was further untangled by a separate assessment of the two different cloud modifications (thickening of liquid clouds, mainly in the solar spectrum, and thinning of ice clouds, mainly in the terrestrial spectrum) to find that the thickening of the liquid cloud contributes $54 \%$ to the total regional forcing, with the remainder from the thinning of ice clouds (figure not shown). An important result of the simulation is that, besides this intended effect, also a high latitude warming is evident over the Alaskan region, which is statistically significant at $90 \%$ confidence level.

From the geographical distribution, the main contributor to the high latitude warming is the anomalous warming simulated to the northwest of the experimental region (Alaskan region). As a consequence of the local cooling, there is a weakening of surface westerly wind flow resulting in an anomalous north to northwesterly flow in the western Pacific 
between $30^{\circ} \mathrm{N}$ and $60^{\circ} \mathrm{N}$ and between $120^{\circ} \mathrm{W}$ and $180^{\circ} \mathrm{W}$ (Figure $2 \mathrm{a}$ ). This anomalous flow favors incursions of warm air masses from mid-latitude to high latitudes. Associated with RRM and high latitude warming, significant changes in circulation and geopotential height are also noted at higher altitudes. The positive anomalies of geopotential and temperature at $500 \mathrm{hPa}$ result in an anomalous anticyclonic circulation over the warm region and a cyclonic circulation over the target region (Figure $2 b$ ).

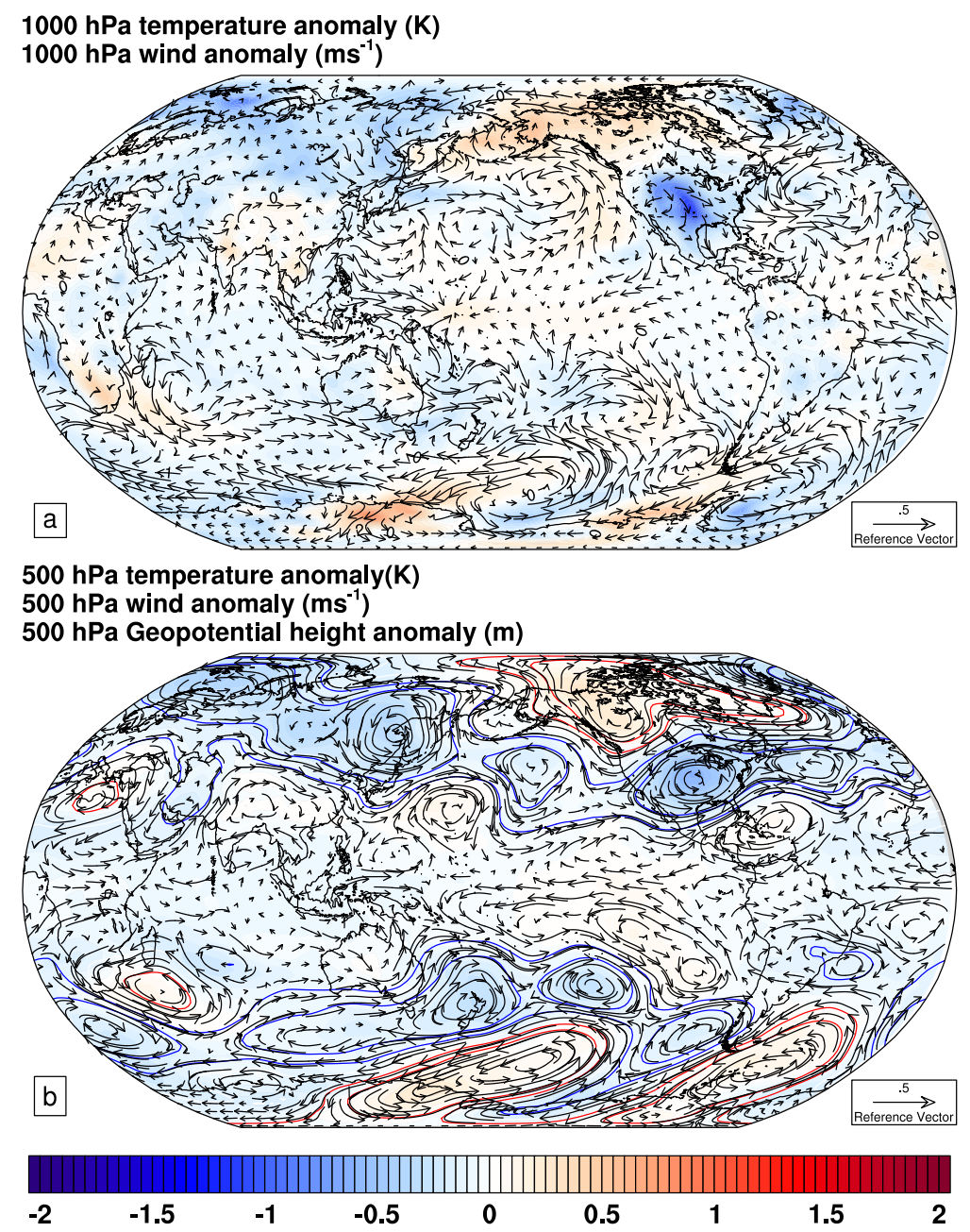

Figure 2. The same as Figure 1 but for: (a) $1000 \mathrm{hPa}$ air temperature (K) and wind vector (ms ${ }^{-1}$ ); and (b) $500 \mathrm{hPa}$ air temperature (color shades), wind vector $\left(\mathrm{ms}^{-1}\right)$, geopotential height ( $\mathrm{m}$, contours from -4 to 4 by 2 ) and wind vector anomaly.

The above circulations result in the convergence of warm air (anticyclonic) and divergence of cold air (cyclonic) above the respective regions. This teleconnection is analogous to the finding of Kug et al. (2015) [78], although it suggests an influence of Arctic warming on North American cold winters, which is the opposite interpretation of causation. Note that, in our simulations, the causation is imposed by construction. There is some seasonality to the results. The colder winters in North America in response to RRM are the major contributor to anomalous Arctic warming. The anomalous cold winter due to RRM cooling provides a favorable condition for the Arctic warming through the poleward intrusion of warm air from mid-latitudes (Figure 2).

Furthermore, the sea ice area fraction shows a decrease over the Alaskan region, which is associated with sustained warming of the Alaskan region due to the North American 
RRM. In turn, in the polar region, the sea ice fraction shows an increase (Figure A3a). The change in sea ice fraction could be related to the seasonality in ERF. It has both contributions from ice and liquid cloud modifications (figure not shown), with a relatively significant negative ERF in the winter season, which leads to seasonality in SAT as well. The seasonality in the RRM induced SAT anomaly (Figure A4) leads to an imbalance between summer ice melt and winter ice growth (Figure A3b,c), which accelerates sea ice loss around the Alaskan region, especially in the Bering Sea and the Sea of Okhotsk.

An even more pronounced effect outside the targeted area is found when considering SAT extremes as defined by the top and bottom deciles of the temporal distribution at each grid point (Figure 3). The geographical distribution of change in the top decile of the SAT shows a cooling of the temperatures over the experiment region and exhibits a spatial pattern that is similar to the mean SAT change pattern, with local cooling. However, in the bottom decile of the SAT distribution, along with the expected reduction over the target area, significant warming is simulated over much of the high latitudes (between $60^{\circ} \mathrm{N}$ and $90^{\circ} \mathrm{N}$ ) of the Northern Hemisphere, with a statistical significance at a confidence level of $90 \%$. Indeed, in the bottom decile of the SAT, the warmings are statistically significant, especially over the Arctic, emphasizing the non-local influence of RRM, attributable to the teleconnection mechanism discussed above. The signal in the bottom decile is noisy, however, with some-less significant—negative anomalies in the high latitudes as well.
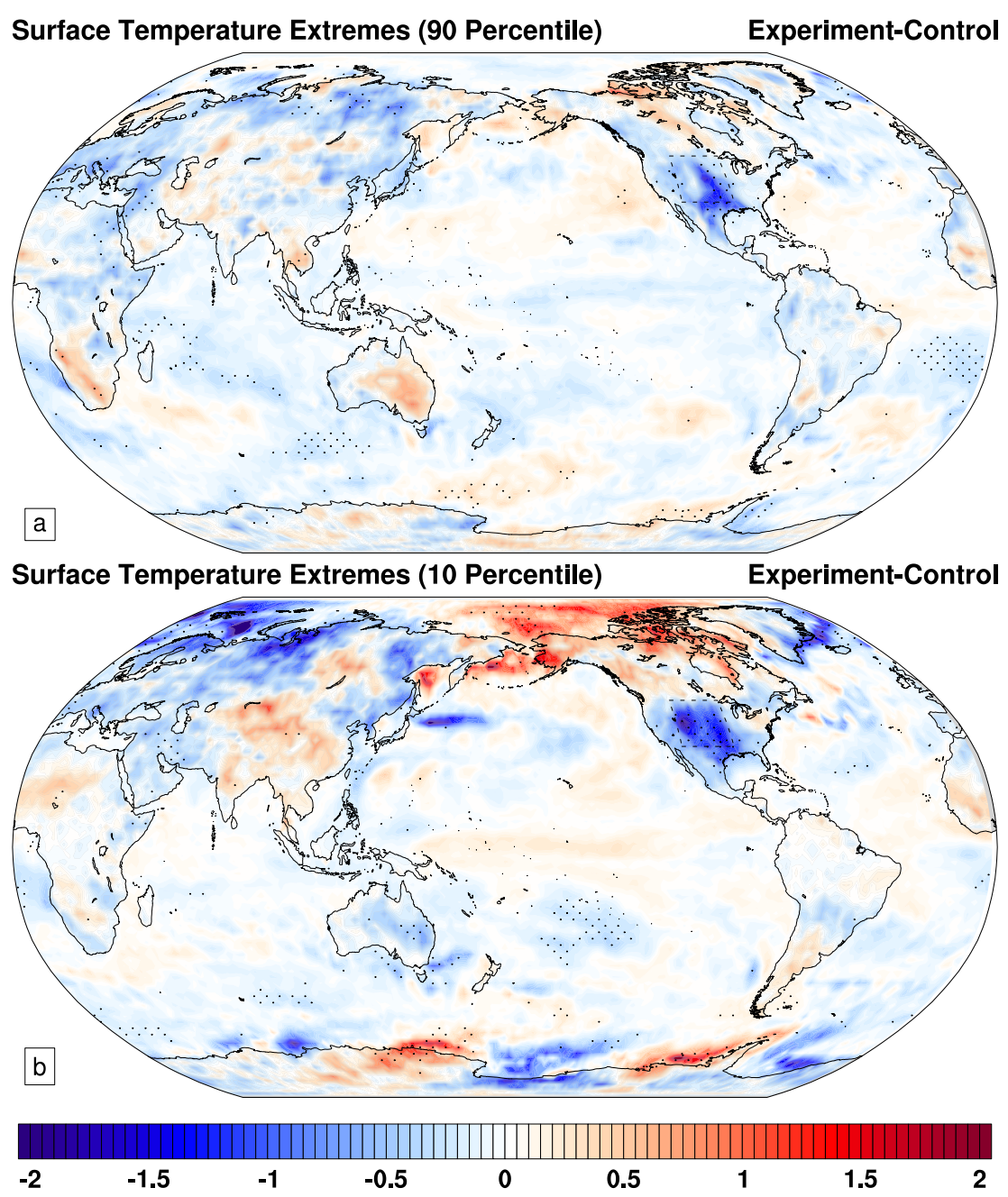

Figure 3. The sam as Figure 1 but for the change in: (a) top decile (90th percentile); and (b) the bottom decile (10th percentile) of the temporal distribution of surface temperature. A $90 \%$ significance level is shown as dotted. 
For precipitation, the RRM simulation shows a slight local increase by on average $0.02 \mathrm{~mm} \mathrm{day}^{-1}$, despite the cooling (Figure 4). However, pronounced alterations of precipitation are also simulated elsewhere across the globe, especially in the eastern Pacific region. The large positive precipitation anomalies in the eastern Pacific warm pool region are related to an RRM teleconnection. It can be delineated from the time series of: (1) standardized SAT anomaly in the RRM region; (2) standardized sea surface temperature (SST) anomaly in the $\mathrm{Ni}$ no3.4 region $\left(5^{\circ} \mathrm{S}\right.$ to $5^{\circ} \mathrm{N}, 120^{\circ} \mathrm{W}$ to $\left.170^{\circ} \mathrm{W}\right)$; and (3) standardized total precipitation anomaly in the eastern Pacific $\left(0^{\circ} \mathrm{S}\right.$ to $10^{\circ} \mathrm{S}, 148^{\circ} \mathrm{W}$ to $\left.180^{\circ} \mathrm{W}\right)$. Figure 5 shows the relationship among SAT, SST and precipitation, each in the distinct regions. Although RRM results in a local reduction in temperature on average, there exists variability in the local cooling. The time series illustrates a negative correlation between SAT in the RRM region with Ni no3.4 SST and precipitation. The negative correlation implies that the intensity of the local RRM cooling has a significant teleconnection to the Pacific warming/cooling which leads to positive/negative precipitation anomalies.

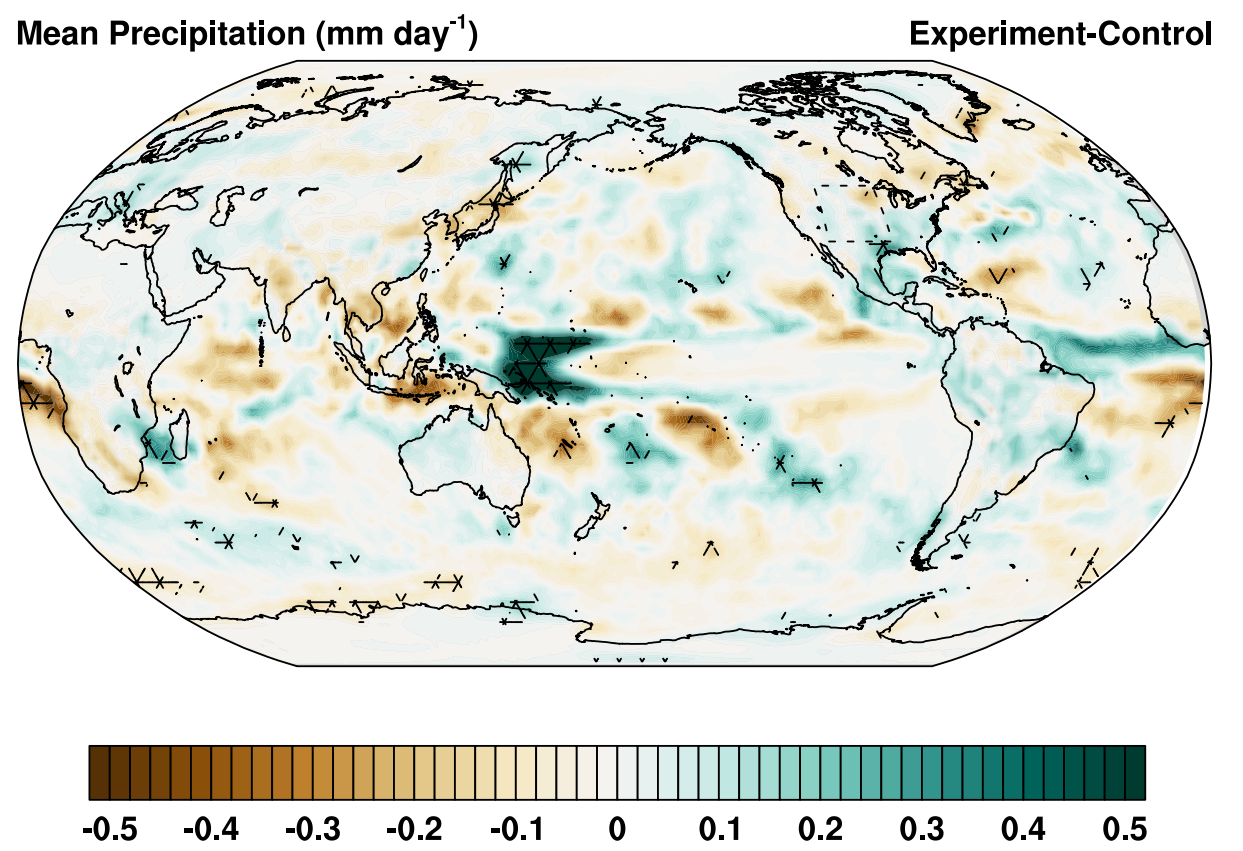

Figure 4. The same as Figure 1 but for change in total precipitation (mm/day).

The teleconnection is further investigated by analyzing the composite anomalies of SAT, precipitation and wind vector when: (1) the standardized SAT anomaly is greater than $-1.0 \mathrm{~K}$; and (2) the standardized SAT anomaly is less than $-1.0 \mathrm{~K}$ in the RRM region. Figure 6 shows the co-variability of the local SAT variability with global climate. During relatively small cooling (SAT $>-1.0 \mathrm{~K}$ ) conditions, the climate variability is analogous to La Ni na conditions with a cool Pacific Ocean SST and a dry western Pacific (Figure 6a). It is associated with a divergent wind vector anomaly in the eastern Pacific along with northerly wind flow, and an anticyclonic circulation over the north-central Pacific, which relates to the warm SAT anomalies. However, periods of strong cooling in the RRM region (SAT anomaly $<-1.0 \mathrm{~K}$ ) relate to climate variability similar to El Ni no conditions (Figure 6b).

During the strong RRM cooling episodes (time periods below the dotted line in Figure 5), relatively strong cooling is simulated over North America and East Asia, while significant warming is simulated for the tropics (central Pacific). In the tropics, SAT patterns reflect the SST pattern. Positive SAT anomalies are also simulated for the high latitudes over the northeast Pacific and extend well into the Alaskan region. As a consequence of significant local cooling, the surface westerly wind weakens and results in an anomalous northerly flow, which contributes to the anomalous warming in the Alaskan region. Additionally, it results 
in an equatorial wind convergence and enhances the convection in the west Pacific, thus the precipitation (Figure 6b).

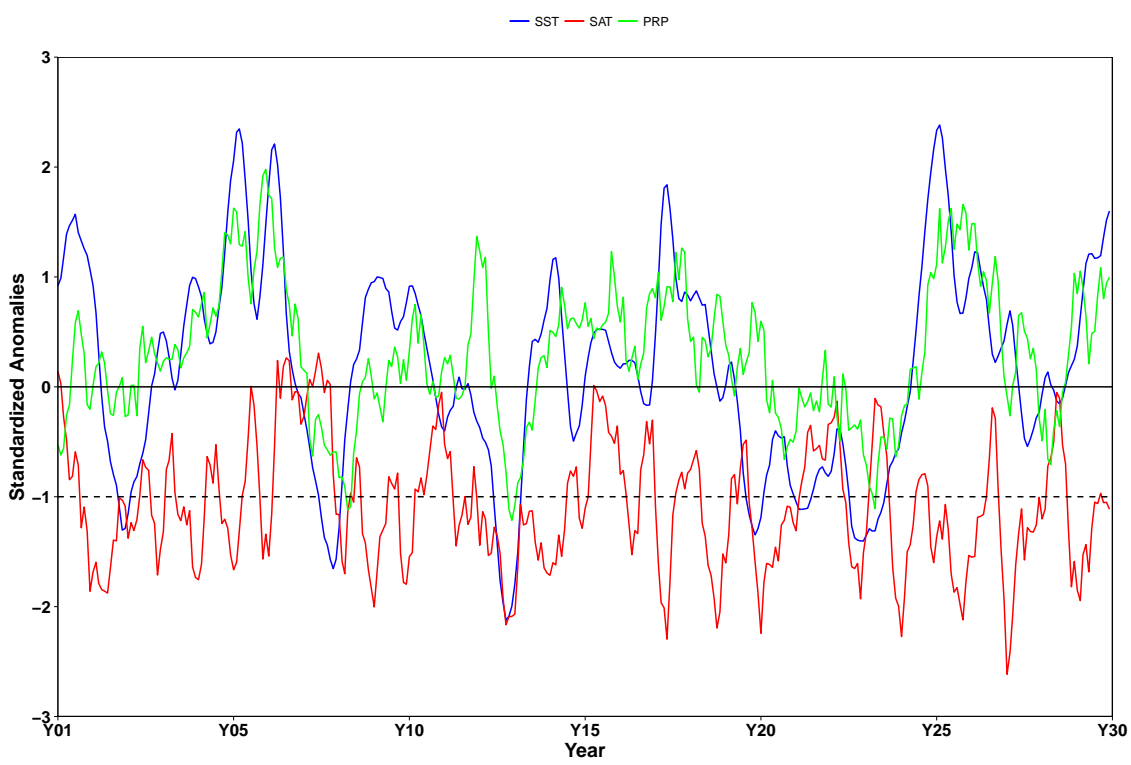

Figure 5. Time evolution of the standardized anomalies of surface air temperature (SAT) in the RRM region (red line), the sea surface temperature (SST) in the Ni no3.4 region $\left(5^{\circ} \mathrm{S}\right.$ to $5^{\circ} \mathrm{N}, 120^{\circ} \mathrm{W}$ to $170^{\circ} \mathrm{W}$, blue line $)$ and total precipitation in the east Pacific region $\left(0^{\circ} \mathrm{S}\right.$ to $-10^{\circ} \mathrm{S}, 148^{\circ} \mathrm{E}$ to $180^{\circ} \mathrm{E}$, green line). The standardized anomalies are averaged for the respective regions. The dashed line shows the SAT at -1.0 in the RRM region, which differentiates the strong and weak cooling scenarios.

Graf and Davide (2012) [79] demonstrated teleconnections between El Ni no and Atlantic/European regional climates, which involve a dynamic coupling of the troposphere with the stratosphere. A similar coupling mechanism is also noticeable when assessing the position of the sub-tropical jet streams in the two simulations (Figure 6). Situations with relatively limited RRM local cooling show little change in the position of the jet (Figure 6a). However, intense local SAT change is correlated with a shift of the jet core towards the Equator over the north Pacific (Figure 6a). This dynamical coupling mechanism can be further explained by upper tropospheric circulations (Figure A5a,b). In the Northern Hemisphere mid-latitudes, the stream function anomalies are similar to the geopotential height anomalies in terms of their pattern, with anti-cyclonic and cyclonic circulation anomalies in the positive and negative stream function positions, respectively. 

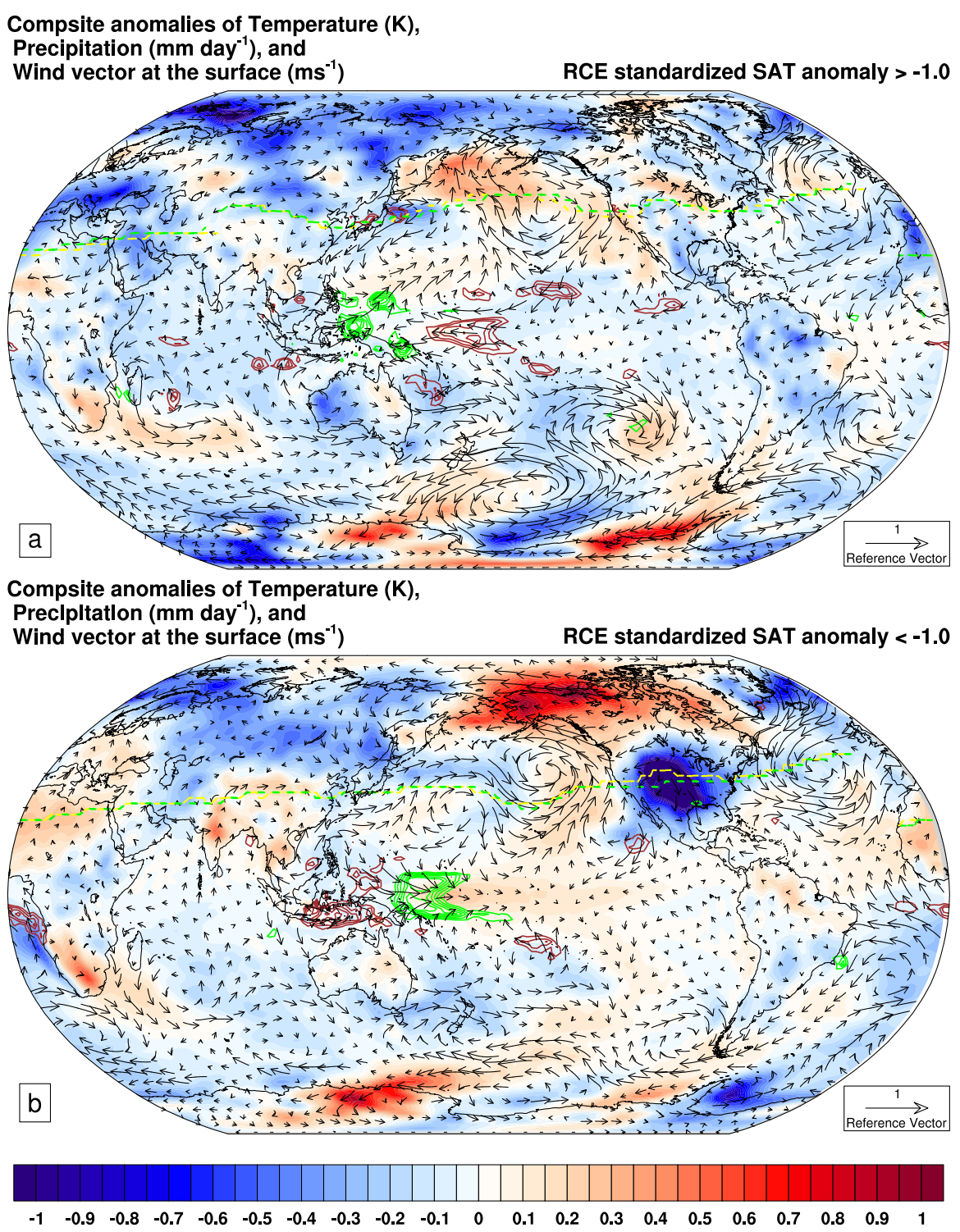

Figure 6. (a) Composite anomalies relative to the control simulation of surface air temperature (SAT in $\mathrm{K}$, color scale), precipitation ( $\mathrm{mm} /$ day, green contours are for positive and brown contours for negative anomalies, contours from -2.0 to 2.0 with a spacing of 0.25$)$ and wind vector $\left(\mathrm{ms}^{-1}\right)$ at the surface for conditions in which the standardized SAT in the RRM region is greater than $-1.0 \mathrm{~K}$; and (b) the same as (a) but for conditions in which the standardized SAT in the RRM region is smaller than $-1.0 \mathrm{~K}$. The green (experiment) and yellow (control) dotted lines represent the core of the jet stream $\left(\mathrm{ms}^{-1}\right.$, max. zonal wind between 300 and $\left.200 \mathrm{hPa}\right)$.

During the time of relatively little RRM cooling (SAT anomaly $>-1.0 \mathrm{~K}$ ), a pronounced chain of significant positive stream function anomalies, as well as anti-cyclonic circulations in the Northern Hemisphere, is simulated. Over the western Pacific, upperlevel convergence can be noticed (Figure 6c). The upper-level convergence and lower-level divergence explain the negative precipitation anomalies (Figures 6a and A5a). On the other hand, composite anomalies for relatively strong RRM cooling (SAT anomaly $<-1.0 \mathrm{~K}$ ) relate to a pronounced chain of significant negative stream function anomalies with cyclonic conditions in the Northern Hemisphere with negative geopotential height field. It appears that the strong low-level convergence and upper-level divergence over the western Pacific lead to pronounced precipitation in this region (Figure $6 \mathrm{~b}$ and $\mathrm{A} 5 \mathrm{~b}$ ). These anomalies are associated with the intensity of RRM cooling, and the proposed link mechanism is the dynamic coupling of the troposphere with the upper troposphere. 
As discussed above, the chosen location for RRM is somewhat arbitrary and it could be applied over other regions as well. Additional experiments with RRM implemented over the central European region indicate that our key conclusion holds. Assuming that clouds can be modified, a regional ERF and thus regional temperature change can be achieved. Furthermore, remote effects outside the target region are also visible (not discussed here).

\subsection{Intermittent Mitigation}

As discussed above, sustained limited-area climate engineering can result in substantial climate alterations in other regions. In light of this, RRM can be less attractive than it initially might seem. Consequently, we now investigate to what extent RRM, if implemented in a temporally intermittent (non-continuous) way, may be useful to suppress harmful extreme weather conditions-here HWs are selected-without causing substantial impact outside the targeted region. Sixteen HWs occur during the three decades of our "intermittent mitigation" simulation (Table 1).

Table 1. An overview of the years, beginning (10 days before HW) and end date (7 days after HW) of the intermittent RRM experiment.

\begin{tabular}{|c|c|c|c|c|}
\hline No & Year No & Begin Date & End Date & HW Length (Days) \\
\hline 1. & Y02 & 1851-07-01 & $1851-08-10$ & 23 \\
\hline 2. & Y04 & 1853-07-19 & $1853-08-10$ & 06 \\
\hline 3. & Y05 & 1854-07-12 & 1854-08-09 & 04 \\
\hline 4. & Y10 & 1859-07-18 & 1859-08-14 & 11 \\
\hline 5. & Y11 & $1860-06-24$ & 1860-07-17 & 07 \\
\hline 6. & Y12 & 1861-07-09 & 1861-08-19 & 06 \\
\hline 7. & Y14 & 1863-06-21 & 1863-08-03 & 04 \\
\hline 8. & Y18 & 1867-06-25 & 1867-07-29 & 09 \\
\hline 9. & Y19 & 1868-08-06 & 1868-08-28 & 06 \\
\hline 10. & Y21 & 1870-07-09 & $1870-08-22$ & 28 \\
\hline 11. & Y24 & 1873-07-15 & $1873-08-03$ & 07 \\
\hline 12. & Y24 & 1874-07-03 & 1874-08-11 & 23 \\
\hline 13. & Y25 & $1875-07-20$ & $1875-08-20$ & 15 \\
\hline 14. & Y27 & $1877-06-22$ & 1877-08-05 & 28 \\
\hline 15. & Y29 & 1878-06-24 & 1879-07-24 & 14 \\
\hline 16. & Y30 & 1879-07-15 & 1879-08-21 & 21 \\
\hline
\end{tabular}

Figure 7 illustrates the evaluation of a case with ensemble mean HW suppression against the corresponding period without HW suppression. The RRM deployed HW suppression leads to local cooling and retains the temperature below the HW threshold temperature of $32{ }^{\circ} \mathrm{C}$. We selected a case for Figure 7 that shows a clear avoidance of the HW, whereas in other cases HW mitigation is not as efficient (Figure A6). In most cases, the mitigation acts to reduce the HW, even if it does not completely avoid exceeding the threshold temperature. The reason is that the magnitude of mitigation strongly depends on the presence of suitable clouds, where the HW with clear skies implies no alteration is introduced. The time average (30 years) of the ERF (Figure $8 b$ ) is much smaller than in the case of the sustained RRM. Similarly, the SAT changes are also much smaller (Figure $8 b$ ). However, a significantly positive SAT anomaly is simulated to the north of the RRM region. Likewise, the temperature extremes, top and bottom deciles of SAT distribution, also reveal a less significant impact outside the target region (Figure $8 \mathrm{c}, \mathrm{d}$ ). However, the bottom decile exhibits an enhanced cooling in the northeastern part and warming to the north of the RRM region. 


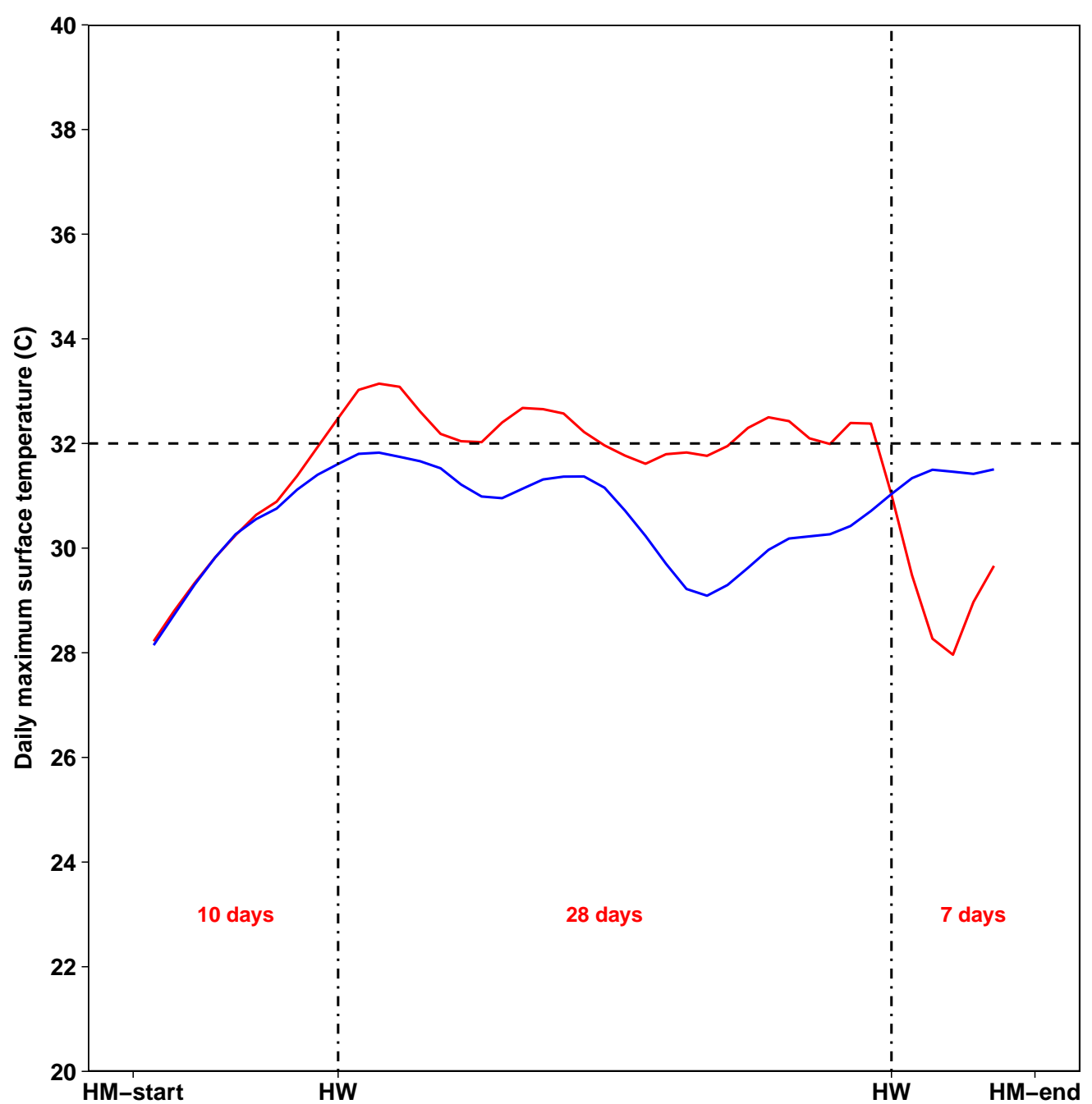

Figure 7. Time evolution of the RRM area-averaged daily maximum surface air temperature $\left({ }^{\circ} \mathrm{C}\right)$ for a HW condition (red line, dark blue simulation with HWs in Figure A2) and the corresponding ensemble mean HW mitigation (blue line), with a heat wave duration in the control of 28 days (refer to Figure A2 for a detailed description of intermittent RRM experiment). The horizontal dotted line at $32{ }^{\circ} \mathrm{C}$ represents the threshold of HWs (refer to Figure A6 for the time evolution of the SAT in all individual identified and suppressed HWs). 


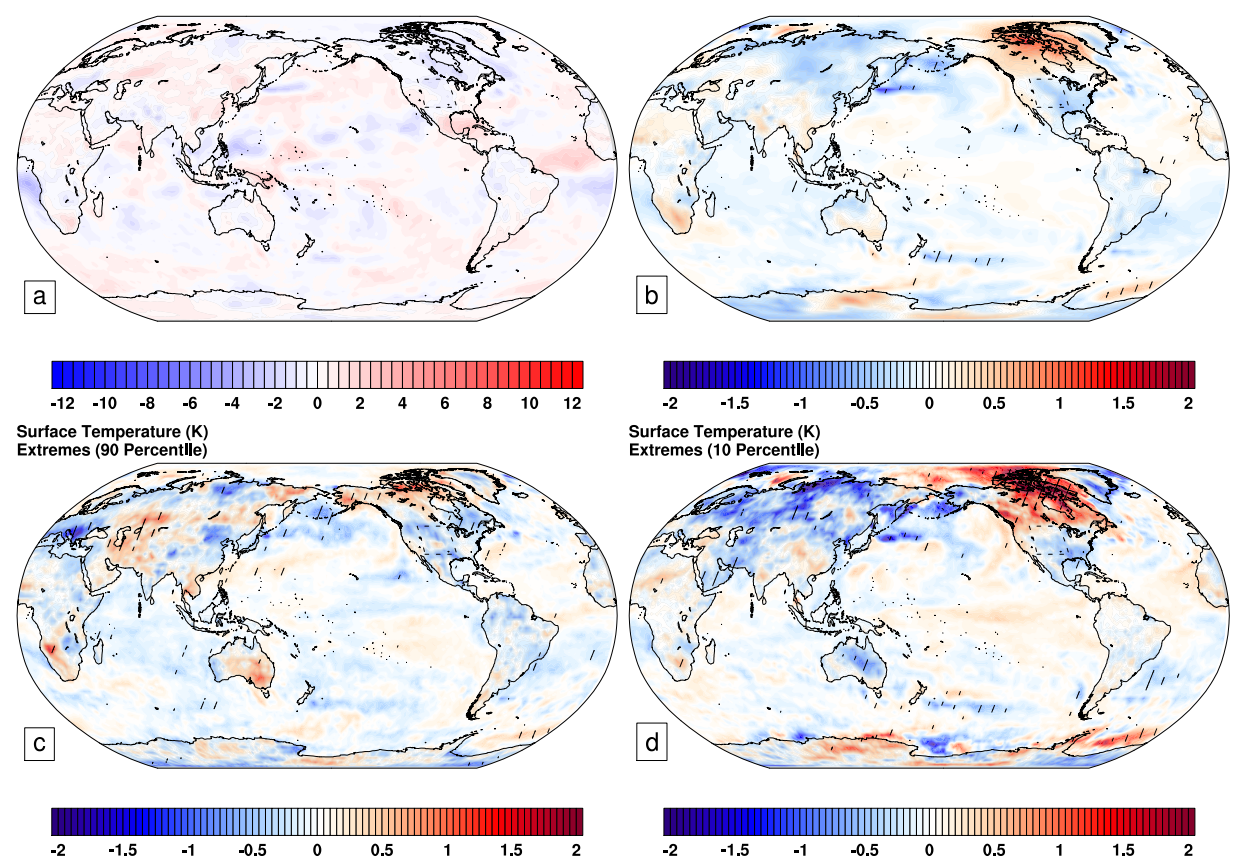

Figure 8. For intermittent RRM simulation: (a) effective radiative forcing (ERF, $\mathrm{Wm}^{-2}$ ) at the top of the atmosphere; and (b) mean change in near-surface air temperature (SAT, K) response. Hatched areas in (b) are grid cells where significant at the $90 \%$ level by the $t$-test. Change in (c) top decile (90th percentile) (d) bottom decile (10th percentile) of temperature distribution. The difference shown are 30-year ensemble ensemble average between the HW suppression and control simulations (In Figure A2, the light blue lines indicate control simulation and the dashed red line in the intermittent simulation represents the ensemble part). Hatched areas in (c,d) are grid cells where significant at the $90 \%$ level by the $t$-test.

These results suggest that intermittent local HW suppression could have potentialalthough not systematic - benefits on human and ecosystem health [61] with smaller side effects than permanent HW suppression. However, we also underline that it is not possible to intervene, even intermittently, without any consequences elsewhere at all.

\section{Conclusions}

It has been suggested that, rather than global CE implementation, RRM might be more plausible from a geopolitical viewpoint as it may be considered by some countries or groups of countries who have their own climate preferences [21]. In this study, we used a coupled climate model, MPI-ESM, to assess the implementation of RRM. This implementation considers an idealized alteration of clouds in the model. For this reason, we employed a modification of cloud properties (only in the radiation module) by scaling both liquid and ice clouds to generate optically thick boundary layer clouds and thinner high clouds, both generating a negative RF. The radiative perturbation resulting from this is quite large and no known technology could achieve it.

However, the experiment is useful in that it provides an estimate for the size of the outcome to be expected for a large perturbation. Any smaller perturbation is expected to have a smaller outcome as well as smaller side effects. Our study addressed the impact of RRM and its consequences. We chose here the example of RRM implemented over North America. Local ERF is $-9.8 \mathrm{Wm}^{-2}$ with a local cooling of $-0.8 \mathrm{~K}$. However, substantial effects outside the target region are also noticed. Especially over the Alaskan region, substantial warming is simulated and can be traced to a weakening of surface westerly wind flow. This warming is enhanced by north and northwesterly flow at the surface, along with $500 \mathrm{hPa}$ anti-cyclonic flow over Alaska and a cyclonic circulation over the target region. 
A slight increase in the local precipitation of $0.02 \mathrm{~mm} \mathrm{day}^{-1}$ is noticed, despite the local cooling. Pronounced precipitation changes are also simulated outside the target area, especially in the eastern Pacific. Our analysis revealed that the relatively strong local RRM cooling results in a weakening of surface westerly wind and leads to equatorial wind convergence over the central Pacific. This, in turn, leads to a warm Pacific Ocean SST anomaly and enhances the precipitation in the eastern Pacific. The upper-level $(200 \mathrm{hPa})$ anomalies for stream function, wind vector and geopotential height also reveal the dynamic coupling of the troposphere with the stratosphere.

In a second step, we studied the feasibility of deploying RRM to mitigate specific harmful weather events that may occur more intensely and more frequently in a warming climate. We chose to target HWs and did so by implementing temporally intermittent RRM, which would presumably lead to less inadvertent effects. The idealized HW suppression scenario assumes accurate predictability of HWs. The results suggest that HWs are mitigated locally with the intermittent implementation of cloud modification by retaining the SAT below the threshold of $32{ }^{\circ} \mathrm{C}$ in some cases. Further, the long-term effect of HW suppression shows that the intermittent RRM results in much smaller time-average forcing, surface temperature, or precipitation changes compared to the sustained RRM. However, some regional changes outside the target region are still simulated.

This study is illustrative of what RRM may look like and what its consequences could be, which relies on a hypothetical scenario [21]. Idealized studies like this one are crucial to quantify the regional effect of $\mathrm{CE}$ and its consequences on neighboring or more remote regions. Most of the RRM studies have focused so far on the polar $[22,38,39,59]$ and oceanic regions $[25,43,44]$, while RRM studies focusing on continental areas are sparse. Such studies are relevant because different countries and regions of the world have different perspectives on climate change and/or CE. Although it is idealized, our study shows that it would not be appropriate to implement RRM unilaterally, if such RRM technologies become available in the future.

Author Contributions: All authors participated in the design of the study. S.D. performed the model simulations, analysis and wrote the paper. All authors assisted in the interpretation of the results and commented on the paper. All authors have read and agreed to the published version of the manuscript.

Funding: This study was funded by the German Research Foundation (Deutsche Forschungsgemeinschaft, DFG) within the Priority Programme SPP 1689 “Climate Engineering - Risks, Challenges, Opportunities?" project LEAC-II (GZQU 311/10-2 and QU 357/3-2).

Institutional Review Board Statement: Not applicable.

Informed Consent Statement: Not applicable.

Data Availability Statement: The data that support the findings of this study is available at http: / / doi.org/10.5281/zenodo.3956312. (accessed on 1 March 2021).

Acknowledgments: The MPI-ESM is developed by the Max Planck Institute for Meteorology, and was run on the facilities of the German Climate Computing Centre (Deutsches Klimarechenzentrum, DKRZ).

Conflicts of Interest: The authors declare that they have no conflict of interest.The funders had no role in the design of the study; in the collection, analyses, or interpretation of data; in the writing of the manuscript, or in the decision to publish the results. 


\section{Appendix A}
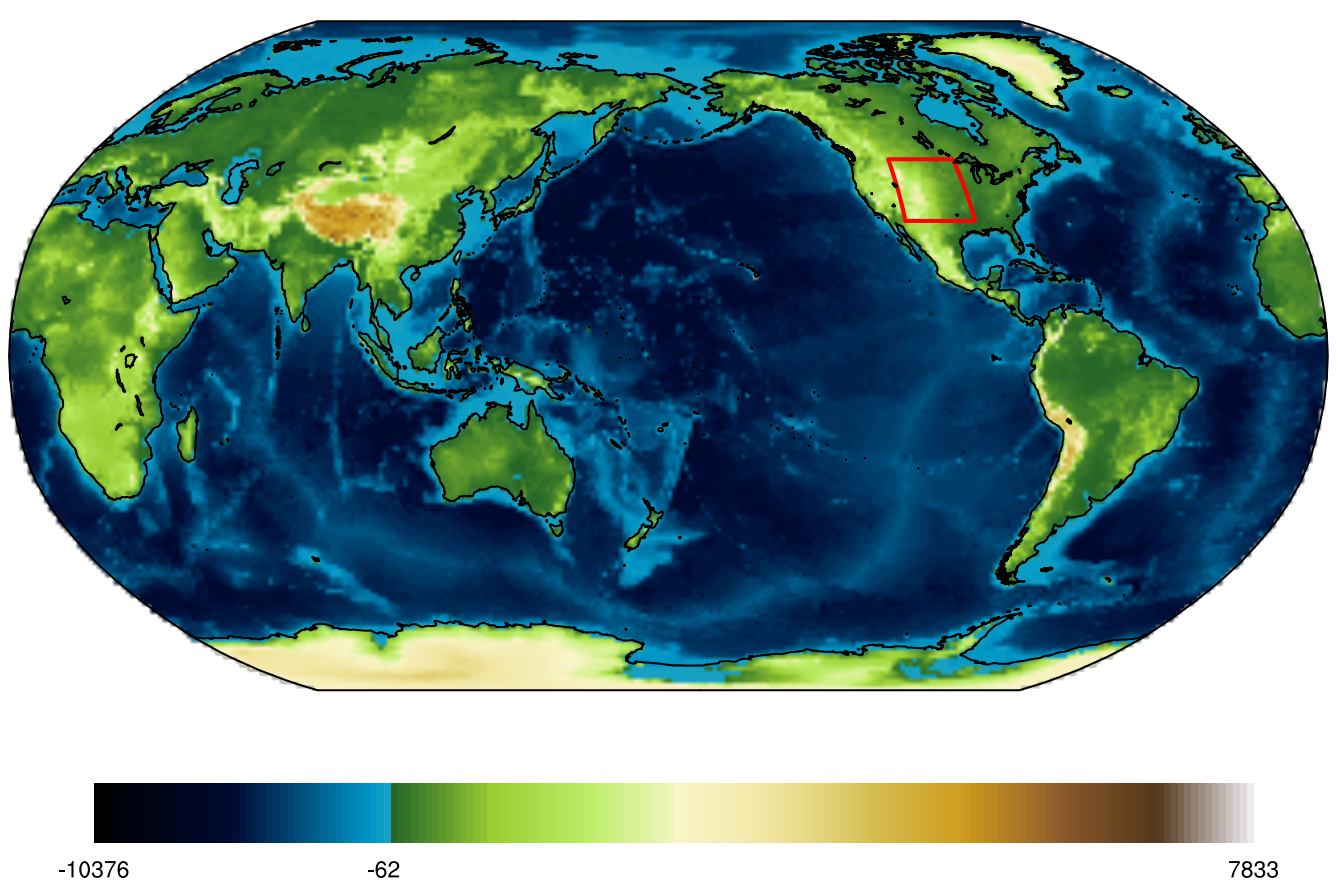

Figure A1. The geographical location of the RRM region $\left(32.5^{\circ} \mathrm{N}\right.$ to $47.5^{\circ} \mathrm{N}, 112.0^{\circ} \mathrm{W}$ to $92.0^{\circ}$ $\mathrm{W}$ ). The blue and the green/brown colors indicate the ocean and the orography, respectively (data sources: [80]).

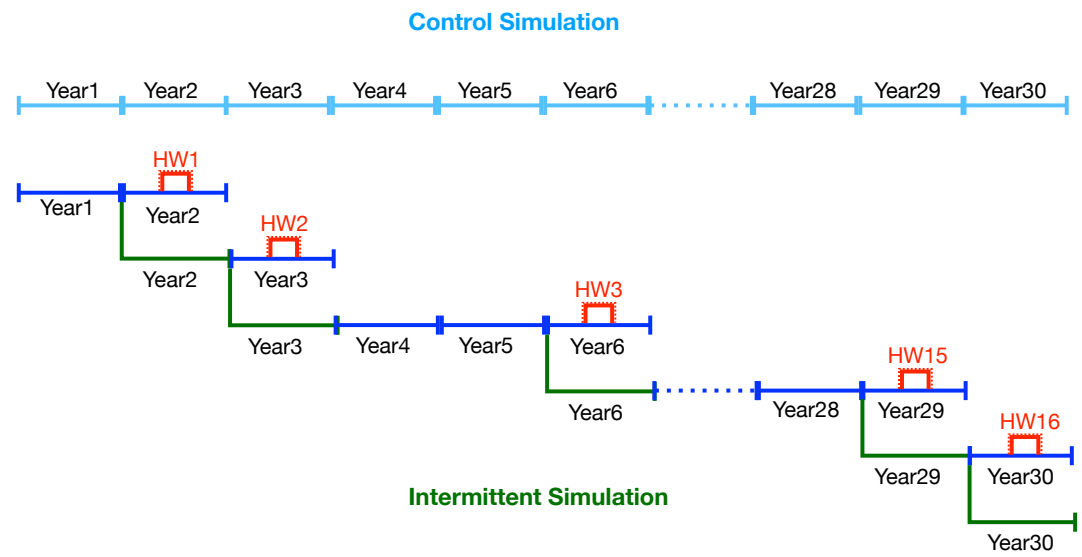

Figure A2. Schematic representations of the control and intermittent simulations. The long-term consequences of HW suppression is estimated from the 30-year mean control and intermittent simulation. The light blue lines indicate control simulation, dark blue lines indicate year without HWs, dark blue lines with red peaks indicate year with HWs and the green lines indicate year with HW suppression. The dashed red line in the intermittent simulation represents the ensemble part. 


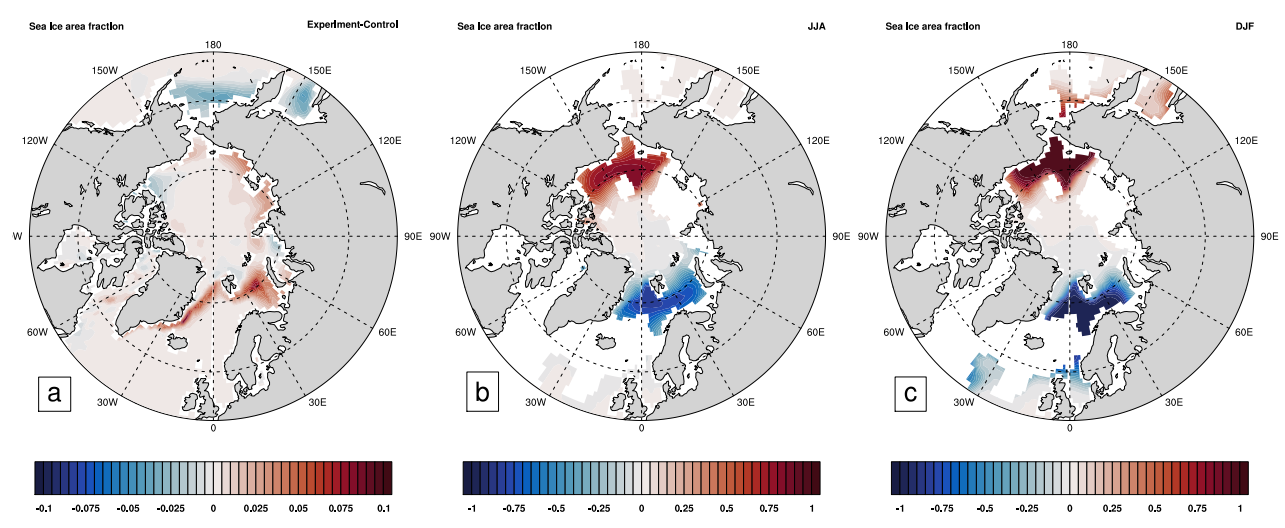

Figure A3. The changes in sea ice area fraction in the Northern Hemisphere due to sustained RRM: (a) in annual mean; (b) during summer (JJA); and (c) during winter (DJF).
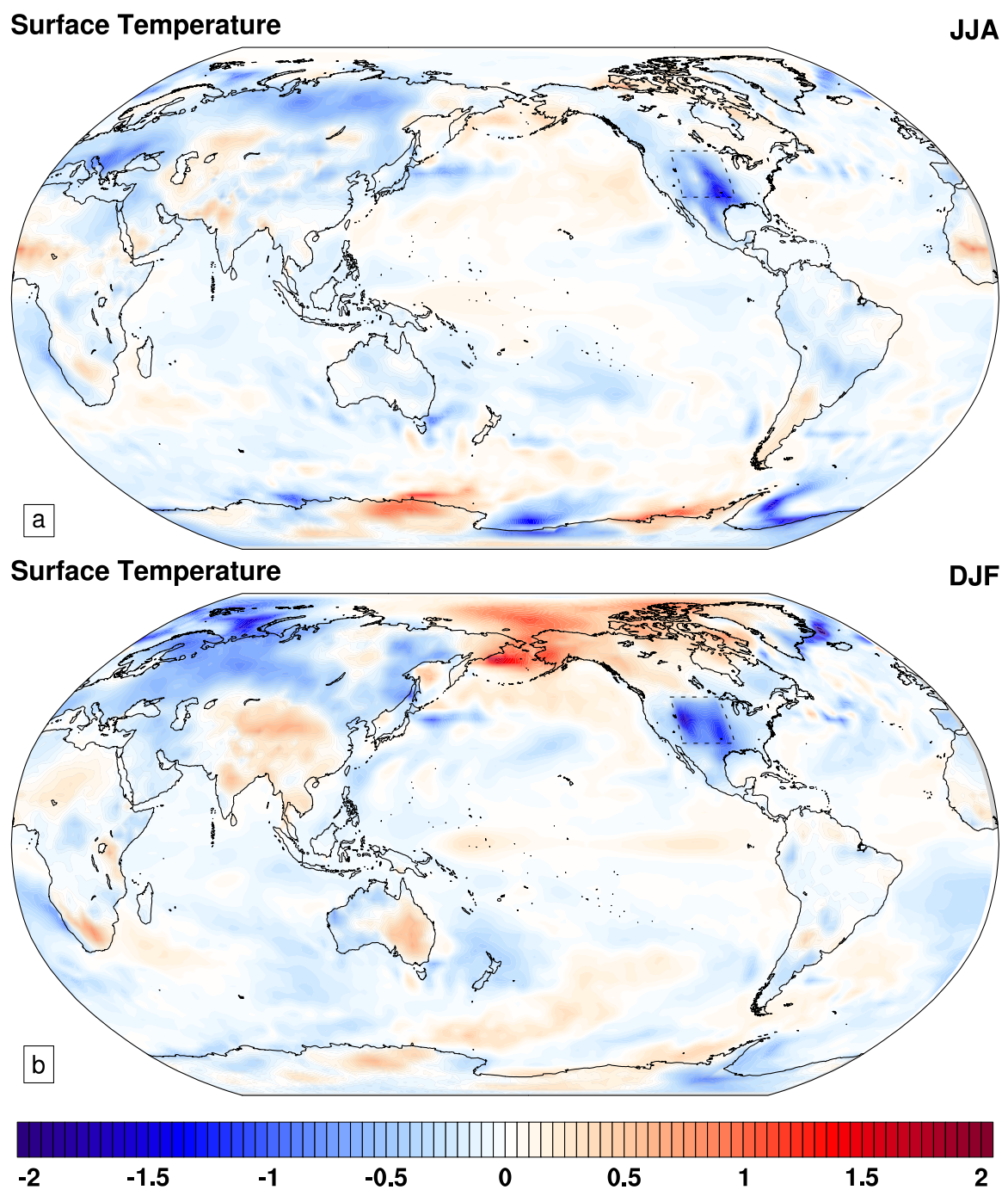

Figure A4. For the sustained RRM simulations, seasonal change in SAT: (a) for the summer season (JJA); and (b) for the winter season (DJF). 


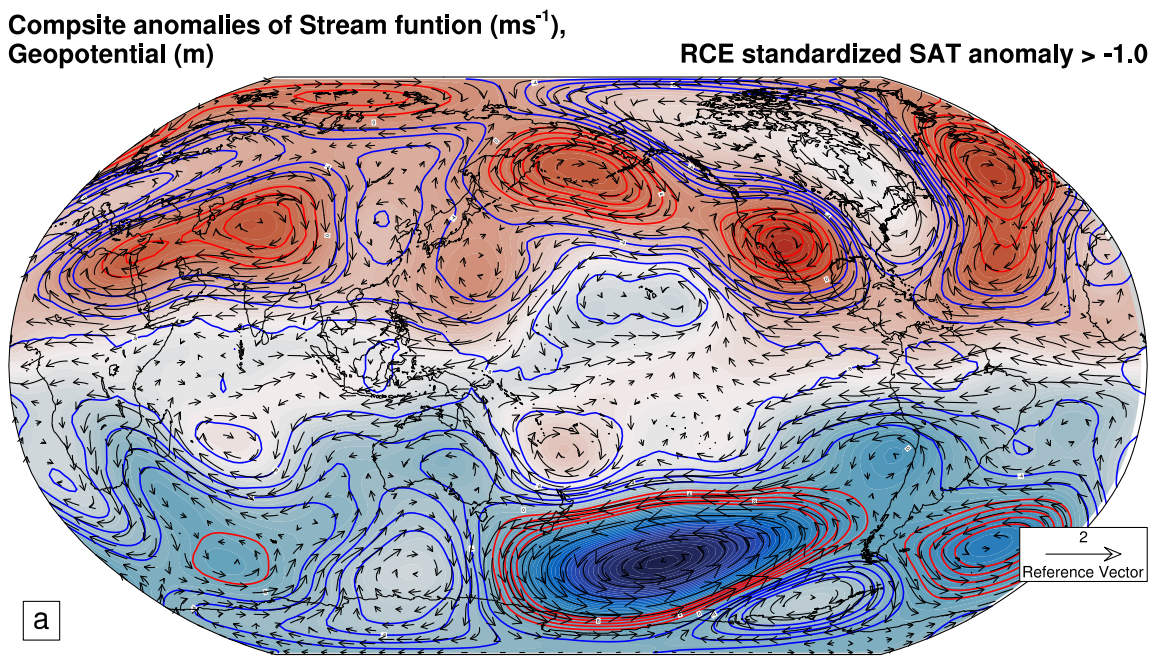

Compsite anomalies of Stream funtion $\left(\mathrm{ms}^{-1}\right)$, Geopotential $(\mathrm{m}) \quad$ RCE standardized SAT anomaly $<-1.0$
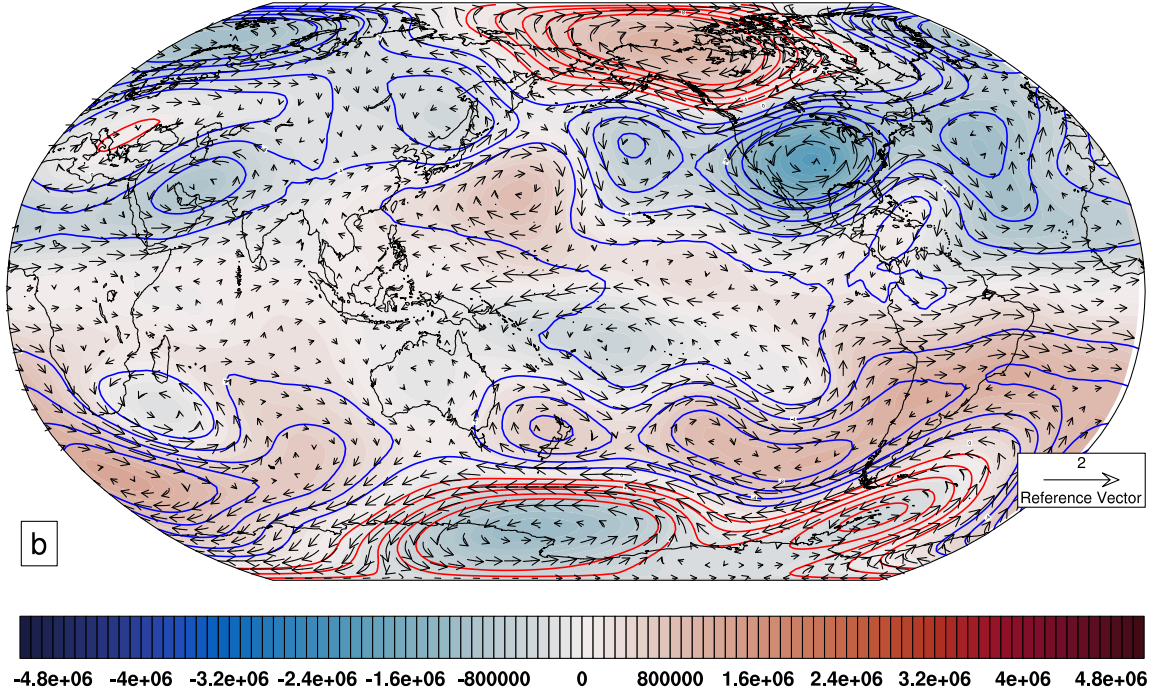

Figure A5. For the sustained RRM simulations: (a) composite anomalies of the stream function $\left(\mathrm{ms}^{-1}\right.$, shaded), wind vector $\left(\mathrm{ms}^{-1}\right)$ and geopotential height $(\mathrm{m}$, red contours are for positive and blue contours for negative anomalies) at $200 \mathrm{hPa}$ for conditions in which the standardized SAT in the RRM region greater than $-1.0 \mathrm{~K}$; and (b) the sam as $(\mathbf{a})$, but for conditions in which the standardized SAT in the RRM region is less than $-1.0 \mathrm{~K}$. 

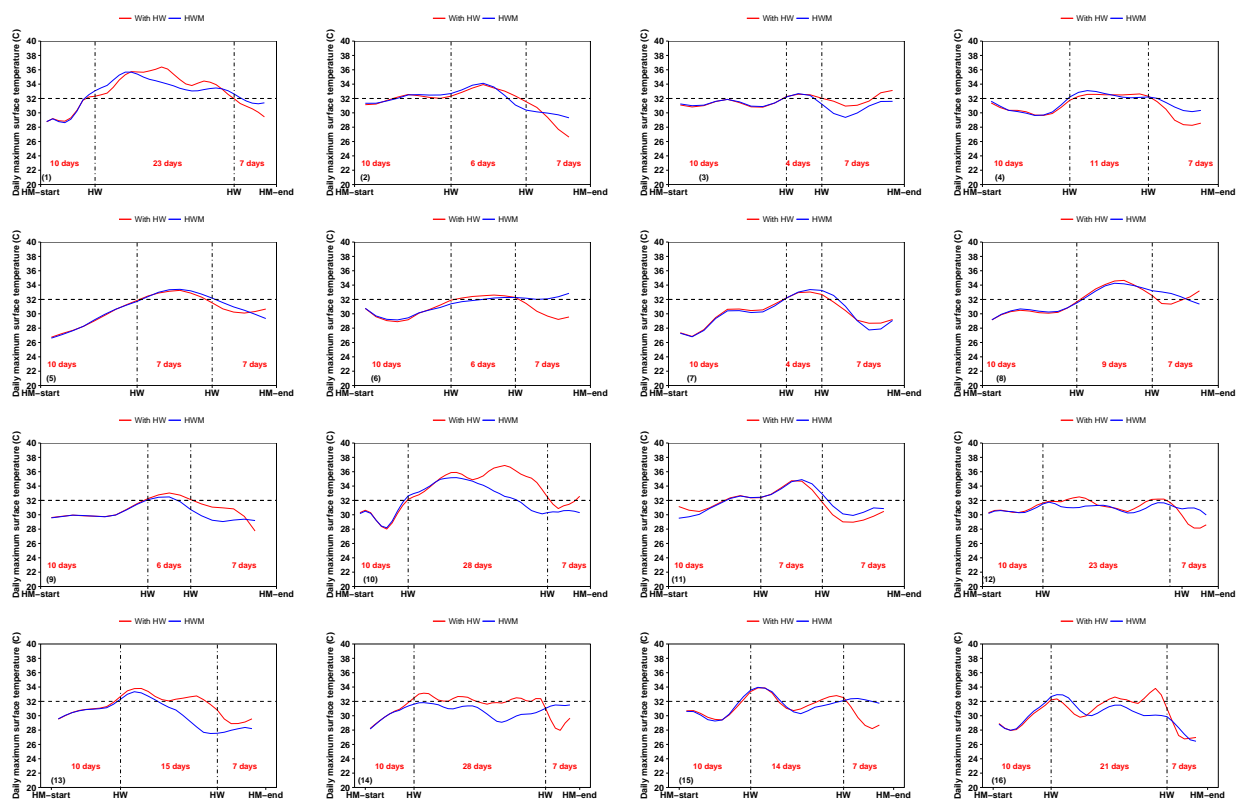

Figure A6. Time evaluations of the area-averaged daily maximum surface air temperature $\left({ }^{\circ} \mathrm{C}\right)$ for the simulation with HW (red curve) and with HW suppression (blue curve).

\section{References}

1. IPCC. Climate Change 2013: The Physical Science Basis. Contribution of Working Group I to the Fifth Assessment Report of the Intergovernmental Panel on Climate Change; Cambridge University Press: Cambridge, UK; New York, NY, USA, $2013 ;$ p. 1535.

2. Boucher, O.; Forster, P.M.; Gruber, N.; Ha-Duong, M.; Lawrence, M.G.; Lenton, T.M.; Maas, A.; Vaughan, N.E. Rethinking climate engineering categorization in the context of climate change mitigation and adaptation. WIREs Clim. Chang. 2014, 5, 23-35. [CrossRef]

3. MacMartin, D.G.; Wang, W.; Kravitz, B.; Tilmes, S.; Richter, J.H.; Mills, M.J. Timescale for Detecting the Climate Response to Stratospheric Aerosol Geoengineering. J. Geophys. Res. 2019, 124, 1233-1247. [CrossRef]

4. Betts, R.A.; Collins, M.; Hemming, D.L.; Jones, C.D.; Lowe, J.A.; Sanderson, M.G. When could global warming reach $4{ }^{\circ}$ C. Phil. Trans. R. Soc. A 2010, 369, 67-84. [CrossRef]

5. $\quad$ Battisti, D.; Blackstock, J.J.; Caldeira, K.; Eardley, D.E.; Katz, J.I.; Keith, D.W.; Koonin, S.E.; Patrinos, A.A.N.; Schrag, D.P.; Socolow, R.H. Climate engineering responses to climate emergencies. IOP Conf. Ser. Earth Environ. Sci. 2009, 6, 452015. [CrossRef]

6. MacCracken, M. Beyond Mitigation: Potential Options For Counter-Balancing The Climatic And Environmental Consequences Of The Rising Concentrations Of Greenhouse Gases; The World Bank: Washington, DC, USA, 2009; pp. 4938-4943.

7. Dimitrov, R. The Paris Agreement on Climate Change: Behind Closed Doors. Global Environ. Polit. 2016, 16, 1-11. [CrossRef]

8. UNFCCC. Adoption of the Paris Agreement, Proposal by the President. 2015. Available online: https://unfccc.int/documents/ 9064 (accessed on 1 March 2021).

9. Keller, D.P.; Feng, E.Y.; Oschlies, A. Potential climate engineering effectiveness and side effects during a high carbon dioxideemission scenario. Nat. Commun. 2014, 5, 3304. [CrossRef]

10. Tilmes, S.; Richter, J.H.; Kravitz, B.; MacMartin, D.G.; Mills, M.J.; Simpson, I.R.; Glanville, A.S.; Fasullo, J.T.; Phillips, A.S.; Lamarque, J.F.; et al. CESM1(WACCM) Stratospheric Aerosol Geoengineering Large Ensemble Project. Bull. Amer. Meteor. Soc. 2018, 99, 2361-2371. [CrossRef]

11. Corner, A.; Pidgeon, N. Geoengineering, climate change scepticism and the 'moral hazard' argument: an experimental study of UK public perceptions. Phil. Trans. R. Soc. A 2014, 372. [CrossRef]

12. Quaas, M.F.; Quaas, J.; Rickels, W.; Boucher, O. Are there reasons against open-ended research into solar radiation management? A model of intergenerational decision-making under uncertainty. J. Environ. Econ. Manag. 2017, 84, 1-17. [CrossRef]

13. Wigley, T.M.L. A Combined Mitigation/Geoengineering Approach to Climate Stabilization. Science 2006, 314, 452-454. [CrossRef]

14. Wigley, T.M.L.; Raper, S.C.B. Interpretation of High Projections for Global-Mean Warming. Science 2001, 293, 451-454. [CrossRef]

15. Rahm, D. Geoengineering Climate Change Solutions: Public Policy issues for National and Global Governance. Humanit. Soc. Sci. Rev. 2018, 08, 139-148.

16. Cox, P.; Huntingford, C.; Williamson, M. Emergent constraint on equilibrium climate sensitivity from global temperature variability. Nature 2018, 553, 319-322. [CrossRef] [PubMed]

17. Preston, C.J. Ethics and geoengineering: reviewing the moral issues raised by solar radiation management and carbon dioxide removal. WIREs Clim. Chang. 2013, 4, 23-37. [CrossRef]

18. Tilmes, S.; Garcia, R.R.; Kinnison, D.E.; Gettelman, A.; Rasch, P.J. Impact of geoengineered aerosols on the troposphere and stratosphere. J. Geophys. Res. 2009, 114. [CrossRef] 
19. Kravitz, B.; Robock, A.; Boucher, O.; Schmidt, H.; Taylor, K.E.; Stenchikov, G.; Schulz, M. The Geoengineering Model Intercomparison Project (GeoMIP). Atmos. Sci. Lett. 2011, 12, 162-167. [CrossRef]

20. Jones, A.C.; Haywood, J.M.; Dunstone, N.; Emanuel, K.; Hawcroft, M.K.; Hodges, K.I.; Jones, A. Impacts of hemispheric solar geoengineering on tropical cyclone frequency. Nat. Commun. 2017, 8, 1382. [CrossRef]

21. Quaas, J.; Quaas, M.F.; Boucher, O.; Rickels, W. Regional climate engineering by radiation management: Prerequisites and prospects. Earth's Future 2016, 4, 618-625. [CrossRef]

22. MacCracken, M.C. The rationale for accelerating regionally focused climate intervention research. Earth's Future 2016, 4, 649-657. [CrossRef]

23. Stjern, C.W.; Muri, H.; Ahlm, L.; Boucher, O.; Cole, J.N.S.; Ji, D.; Jones, A.; Haywood, J.; Kravitz, B.; Lenton, A.; et al. Response to marine cloud brightening in a multi-model ensemble. Atmos. Chem. Phys. 2018, 18, 621-634. [CrossRef]

24. Aswathy, V.N.; Boucher, O.; Quaas, M.; Niemeier, U.; Muri, H.; Mülmenstädt, J.; Quaas, J. Climate extremes in multi-model simulations of stratospheric aerosol and marine cloud brightening climate engineering. Atmos. Chem. Phys. 2015, 15, 9593-9610. [CrossRef]

25. Jones, A.; Haywood, J.; Boucher, O. Climate impacts of geoengineering marine stratocumulus clouds. J. Geophys. Res. 2009, 114, D10106. [CrossRef]

26. Mitchell, D.L.; Finnegan, W. Modification of cirrus clouds to reduce global warming. Environ. Res. Lett. 2009, 4, 045102. [CrossRef]

27. Barker, T.; Bashmakov, I.; Bernstein, L.; Bogner, J.; Bosch, P.; Dave, R.; Davidson, O.; Fisher, B.; Grubb, M.; Gupta, S.; et al. Technical Summary. In Climate Change 2007: Mitigation; Cambridge University Press: Cambridge, UK, 2007.

28. Mitchell, D.L.; Philip, R.; Dorothea, I.; Greg, M.; Timo, N. Impact of small ice crystal assumptions on ice sedimentation rates in cirrus clouds and GCM simulations. Geophys. Res. Lett. 2008, 35. [CrossRef]

29. Robock, A.; Oman, L.; Stenchikov, G.L. Regional climate responses to geoengineering with tropical and Arctic $\mathrm{SO}_{2}$ injections. J. Geophys. Res. 2008, 113, D16101. [CrossRef]

30. Matthews, H.D.; Caldeira, K. Transient climate-carbon simulations of planetary geoengineering. Proc. Natl. Acad. Sci. USA 2007, 104, 9949-9954. [CrossRef]

31. Carr, W.A.; Preston, C.J.; Yung, L.; Szerszynski, B.; Keith, D.W.; Mercer, A.M. Public engagement on solar radiation management and why it needs to happen now. Clim. Chang. 2013, 121, 567-577. [CrossRef]

32. Moreno-Cruz, J.B.; Ricke, K.L.; Keith, D.W. A simple model to account for regional inequalities in the effectiveness of solar radiation management. Clim. Chang. 2012, 110, 649-668. [CrossRef]

33. Keith, D.; Parson, E.; Morgan, M.G. Research on global sun block needed now. Nature 2010, 463, 426-427. [CrossRef] [PubMed]

34. Heckendorn, P.; Weisenstein, D.; Fueglistaler, S.; Luo, B.P.; Rozanov, E.; Schraner, M.; Thomason, L.W.; Peter, T. The impact of geoengineering aerosols on stratospheric temperature and ozone. Environ. Res. Lett. 2009, 4, 045108. [CrossRef]

35. MacMartin, D.G.; Kravitz, B.; Tilmes, S.; Richter, J.H.; Mills, M.J.; Lamarque, J.F.; Tribbia, J.J.; Vitt, F. The Climate Response to Stratospheric Aerosol Geoengineering Can Be Tailored Using Multiple Injection Locations. J. Geophys. Res. 2017, 122, 12574-12590. [CrossRef]

36. MacMartin, D.G.; Kravitz, B. Mission-driven research for stratospheric aerosol geoengineering. Proc. Natl. Acad. Sci. USA 2019, 116, 1089-1094. [CrossRef] [PubMed]

37. Jones, A.; J, H.; Olivier, B.; Ben, K.; Robock, A. Geoengineering by stratospheric $\mathrm{SO}_{2}$ injection: results from the Met Office HadGEM2 climate model and comparison with the Goddard Institute for Space Studies ModelE. Atmos. Chem. Phys. 2010, 10, 5999-6006. [CrossRef]

38. MacCracken, M.C.; Shin, H.J.; Caldeira, K.; Ban-Weiss, G.A. Climate response to imposed solar radiation reductions in high latitudes. Earth Syst. Dyn. 2013, 4, 301-315. [CrossRef]

39. Caldeira, K.; Wood, L. Global and Arctic climate engineering: numerical model studies. Phil. Trans. R. Soc. A 2008, 366, 4039-4056. [CrossRef] [PubMed]

40. Haywood, J.M.; Jones, A.; Bellouin, N.; Stephenson, D. Asymmetric forcing from stratospheric aerosols impacts Sahelian rainfall. Nat. Clim. Chang. 2013, 3, 660-665. [CrossRef]

41. Tilmes, S.; Fasullo, J.; Lamarque, J.F.; Marsh, D.R.; Mills, M.; AlterskjÃŠr, K.; Muri, H.; KristjÃ jnsson, J.E.; Boucher, O.; Schulz, M.; et al. The hydrological impact of geoengineering in the Geoengineering Model Intercomparison Project (GeoMIP). J. Geophys. Res. 2013, 118, 11,036-11.058. [CrossRef]

42. Crutzen, P.J. Albedo Enhancement by Stratospheric Sulfur Injections: A Contribution to Resolve a Policy Dilemma? Clim. Chang. 2006, 77, 211. [CrossRef]

43. Wood, R.; Ackerman, T.P. Defining success and limits of field experiments to test geoengineering by marine cloud brightening. Clim. Chang. 2013, 121, 459-472. [CrossRef]

44. Latham, J.; Bower, K.; Choularton, T.; Coe, H.; Connolly, P.; Cooper, G.; Craft, T.; Foster, J.; Gadian, A.; Galbraith, L.; et al. Marine cloud brightening. Phil. Trans. R. Soc. A 2012, 370, 4217-4262. [CrossRef]

45. Latham, J. Control of global warming? Nature 1990, 347, 339-340. [CrossRef]

46. Twomey, S. The Influence of Pollution on the Shortwave Albedo of Clouds. J. Atmos. Sci. 1977, 34, 1149-1152. [CrossRef]

47. Robock, A.; MacMartin, D.G.; Duren, R.; Christensen, M.W. Studying geoengineering with natural and anthropogenic analogs. Clim. Chang. 2013, 121, 445-458. [CrossRef] 
48. Latham, J. Amelioration of global warming by controlled enhancement of the albedo and longevity of low-level maritime clouds. Atmos. Sci. Lett. 2002, 3, 52-58. [CrossRef]

49. Kosugi, T. Fail-safe solar radiation management geoengineering. Mitig. Adapt. Strateg. Glob. Chang. 2013, 18, 1141-1166. [CrossRef]

50. Brovkin, V.; Petoukhov, V.; Claussen, M.; Bauer, E.; Archer, D.; Jaeger, C. Geoengineering climate by stratospheric sulfur injections: Earth system vulnerability to technological failure. Clim. Chang. 2009, 92, 243-259. [CrossRef]

51. Parker, A.; Irvine, P.J. The Risk of Termination Shock From Solar Geoengineering. Earth's Future 2018, 6, 456-467. [CrossRef]

52. Duan, L.; Cao, L.; Bala, G.; Caldeira, K. Comparison of the Fast and Slow Climate Response to Three Radiation Management Geoengineering Schemes. J. Geophys. Res. 2018, 123, 11980-12001. [CrossRef]

53. Gruber, S.; Blahak, U.; Haenel, F.; Kottmeier, C.; Leisner, T.; Muskatel, H.; Storelvmo, T.; Vogel, B. A process study on thinning of Arctic winter cirrus clouds with high-resolution ICON-ART simulations. J. Geophys. Res. 2019, 124. [CrossRef]

54. Muri, H.; Kristjánsson, J.E.; Storelvmo, T.; Pfeffer, M.A. The climatic effects of modifying cirrus clouds in a climate engineering framework. J. Geophys. Res. 2014, 119, 4174-4191. [CrossRef]

55. Storelvmo, T.; Boos, W.R.; Herger, N. Cirrus cloud seeding: a climate engineering mechanism with reduced side effects? Phil. Trans. R. Soc. A 2014, 372. [CrossRef] [PubMed]

56. Campbell, J.R.; Peterson, D.A.; Marquis, J.W.; Fochesatto, G.J.; Vaughan, M.A.; Stewart, S.A.; Tackett, J.L.; Lolli, S.; Lewis, J.R.; Oyola, M.I.; et al. Unusually Deep Wintertime Cirrus Clouds Observed over the Alaskan Subarctic. Bull. Am. Meteorol. Soc. 2018, 99, 27-32. [CrossRef] [PubMed]

57. Masunaga, H.; Bony, S. Radiative Invigoration of Tropical Convection by Preceding Cirrus Clouds. J. Atmos. Sci 2018, 75, 1327-1342. [CrossRef]

58. Storelvmo, T.; Kristjansson, J.E.; Muri, H.; Pfeffer, M.; Barahona, D.; Nenes, A. Cirrus cloud seeding has potential to cool climate. Geophys. Res. Lett. 2013, 40, 178-182. [CrossRef]

59. Tilmes, S.; Jahn, A.; Kay, J.E.; Holland, M.; Lamarque, J.F. Can regional climate engineering save the summer Arctic sea ice? Geophys. Res. Lett. 2014, 41, 880-885. [CrossRef]

60. Ge, F.; Zhu, S.; Peng, T.; Zhao, Y.; Sielmann, F.; Fraedrich, K.; Zhi, X.; Liu, X.; Tang, W.; Ji, L. Risks of precipitation extremes over Southeast asia: does $1.5^{\circ} \mathrm{C}$ or $2^{\circ} \mathrm{C}$ global warming make a difference? Environ. Res. Lett. 2019, 14, 044015. [CrossRef]

61. Herring, S.C.; Hoerling, M.P.; Peterson, T.C.; Stott, P.A. Explaining Extreme Events of 2013 from a Climate Perspective. Bull. Amer. Meteor. Soc. 2014, 95, S1-S104. [CrossRef]

62. Wolf, J.; Adger, W.N.; Lorenzoni, I.; Abrahamson, V.; Raine, R. Social capital, individual responses to heat waves and climate change adaptation: An empirical study of two UK cities. Glob. Environ. Chang. 2010, 20, 44-52. [CrossRef]

63. Sun, Y.; Zhang, X.; Zwiers, F.W.; Song, L.; Wan, H.; Hu, T.; Yin, H.; Ren, G. Rapid increase in the risk of extreme summer heat in Eastern China. Nat. Clim. Chang. 2014, 4, 1082-1085. [CrossRef]

64. Jones, G.S.; Stott, P.A.; Nikolaos, C. Human contribution to rapidly increasing frequency of very warm Northern Hemisphere summers. J. Geophys. Res. 2008, 113. [CrossRef]

65. Meehl, G.A.; Tebaldi, C. More Intense, More Frequent, and Longer Lasting Heat Waves in the 21st Century. Science 2004, 305, 994-997. [CrossRef] [PubMed]

66. Sillmann, J.; Kharin, V.V.; Zhang, X.; Zwiers, F.W.; Bronaugh, D. Climate extremes indices in the CMIP5 multimodel ensemble: Part 1. Model evaluation in the present climate. J. Geophys. Res. 2013, 118, 1716-1733. [CrossRef]

67. Wang, M.; Yan, X.; Liu, J.; Zhang, X. The contribution of urbanization to recent extreme heat events and a potential mitigation strategy in the Beijing-Tianjin-Hebei metropolitan area. Theor. Appl. Climatol. 2013, 114, 407-416. [CrossRef]

68. Keith, D.W.; MacMartin, D.G. A temporary, moderate and responsive scenario for solar geoengineering. Nat. Clim. Chang. 2015, 5, 201-206. [CrossRef]

69. Irvine, P.; Emanuel, K.; He, J.; Horowitz, L.W.; Vecchi, G.; Keith, D. Halving warming with idealized solar geoengineering moderates key climate hazards. Nat. Clim. Chang. 2019, 9, 295-299. [CrossRef]

70. Sugiyama, M.; Arino, Y.; Kosugi, T.; Kurosawa, A.; Watanabe, S. Next steps in geoengineering scenario research: limited deployment scenarios and beyond. Clim. Policy 2018, 18, 681-689. [CrossRef]

71. Giorgetta, M.A.; Jungclaus, J.; Reick, C.H.; Legutke, S.; Bader, J.; Böttinger, M.; Brovkin, V.; Crueger, T.; Esch, M.; Fieg, K.; et al. Climate and carbon cycle changes from 1850 to 2100 in MPI-ESM simulations for the Coupled Model Intercomparison Project phase 5. J. Adv. Model. Earth Syst. 2013, 5, 572-597. [CrossRef]

72. Stevens, B.; Giorgetta, M.; Esch, M.; Mauritsen, T.; Crueger, T.; Rast, S.; Salzmann, M.; Schmidt, H.; Bader, J.; Block, K.; et al. Atmospheric component of the MPI-M Earth System Model: ECHAM6. J. Adv. Model. Earth Syst. 2013, 5, 146-172. [CrossRef]

73. Jungclaus, J.H.; Fischer, N.; Haak, H.; Lohmann, K.; Marotzke, J.; Matei, D.; Mikolajewicz, U.; Notz, D.; von Storch, J.S. Characteristics of the ocean simulations in the Max Planck Institute Ocean Model (MPIOM) the ocean component of the MPI-Earth system model. J. Adv. Model. Earth Syst. 2013, 5, 422-446. [CrossRef]

74. Milinski, S.; Maher, N.; Olonscheck, D. How large does a large ensemble need to be? Earth Syst. Dyn. 2020, 11, 885-901. [CrossRef]

75. Welch, B.L. The Generalization of 'Student's' Problem When Several Different Population Variances Are Involved. Biometrika 1947, 34, 28-35. [CrossRef] [PubMed]

76. Boneau, C.A. The effects of violations of assumptions underlying the $t$ test. Psychol. Bull. 1960, 57, 49-64. [CrossRef] [PubMed] 
77. McComiskey, A.; Feingold, G. Quantifying error in the radiative forcing of the first aerosol indirect effect. Geophys. Res. Lett. 2008, 35. [CrossRef]

78. Kug, J.S.; Jeong, J.H.; Jang, Y.S.; Kim, B.M.; Folland, C.K.; Min, S.K.; Son, S.W. Two distinct influences of Arctic warming on cold winters over North America and East Asia. Nat. Geosci. 2015, 8, 759-762. [CrossRef]

79. Graf, H.; Davide, Z. Central Pacific El Ni no, "the subtropical bridge", and Eurasian climate. J. Geophys. Res. 2012, 117. [CrossRef]

80. Hastings, D.A.; Dunbar, P.K.; Elphingstone, G.M.; Bootz, M.; Murakami, H.; Maruyama, H.; Masaharu, H.; Holland, P.; Payne, J.; Bryant, N.A.; et al. The Global Land One-kilometer Base Elevation (GLOBE) Digital Elevation Model, Version 1.0; National Oceanic and Atmospheric Administration, National Geophysical Data Center: Boulder, CO, USA, 1999. 